\title{
Osmanlı Hanedanının Evlilik Politikaları ve Mihrimah Sultan'ın Evliliği
}

\section{Ottoman Dynastic Marriage Politics and Mihrimah Sultan's Marriage}

\author{
Zahit Atçıl'
}

'Sorumlu yazar/Corresponding author: Zahit Atçı (Dr. Öğr. Üyesi),

İstanbul Medeniyet Üniversitesi, Edebiyat Fakültesi, Tarih Bölümü, İstanbul, Türkiye E-posta: zahit.atcil@medeniyet.edu.tr ORCID: 0000-0002-1505-7769

Başvuru/Submitted: 05.09.2020 Revizyon Talebi/Revision Requested: 30.09.2020

Son Revizyon/Last Revision Received: 10.11.2020

Kabul/Accepted: 13.11.2020

Atıf/Citation: Atcil, Zahit, "Osmanlı Hanedanının Evlilik Politikaları ve Mihrimah Sultan'ın Evliliği", Güneydoğu Avrupa Araștırmaları Dergisi, 34 (2020), s. 1-26. https://doi.org/10.26650/gaad.20213401

\section{öz}

Bu çalışma Kanuni Sultan Süleyman'ın tek kızı Mihrimah Sultan'ın (1522-1578) evliliğini Osmanlı hanedanının evlilik politikaları çerçevesinde incelemektedir. Osmanlı hanedanı başlangıçta komşu Müslüman beyliklerle ve Bizans elitleri ile evlilik bağları kurmuş, bu evlilikler aracılığı ile kendini devam ettirmiştir. 15. yüzyılda ise hanedanın sürekliliğinde cariyelerin oranı giderek artmış ve 16 . yüzyılın başına gelindiğinde hanedanın üyeleri nikah kıyarak evliliği bırakmıştı. Bu dönüşüm Osmanlı hanedanının artan prestiji ile de bağlantılıydı. 16. yüzyılda Osmanlı hanedanı evlilik politikalarında nikahlı eşler yerine cariyeleri tercih ederken, hanedanın kızları da gelecek vadeden yöneticiler ile evlendirilmiştir. Bu evlilikler hanedana damat olanların kariyerlerinin daha hızlı ilerlemesine yardımcı olmuştur. Bu bağlamda Kanuni Sultan Süleyman'ın kızı Mihrimah da sultanın gözüne girmeyi başarmış Rüstem Paşa ile evlendirilmiştir. Rüstem, Mihrimah ile evliliği sayesinde kariyer basamaklarında hızlıca yükselmiş ve yüzyıl ortalarında geniş yetkilerle sadrazamlığa ulaşmıştır. 1553'te Şehzade Mustafa'nın sultan tarafından öldürülmesindeki dahli sebebiyle bir müddet görevinden azledilmiş ama kısa sürede yeniden sadrazamlık makamına getirilmiştir. Mihrimah ile evli olması, Rüstem'in gücünü ve saygınlığını devam ettirmesine yardımcı olmuştur. Bu çalışma, mevcut tarihi kaynaklar ışığında Mihrimah Sultan'ın evliliğinin süreçlerini, aşamalarını ve dönüm noktalarııı incelemektedir. Özelllikle, muhtemel damat adayları arasından Rüstem Paşa'nın nasıl seçildiğini, çiftin düğün merasimini ve sonrasındaki evlilik hayatını, bu evlilikten doğan Ayşe Hümaşah'ı ve iddia edilen diğer çocuklarını, Rüstem Paşa'nın 1561'de ölümünden sonra Mihrimah Sultan'ın hayatını ve siyasete etkisini tartışmaktadır.

Anahtar Kelimeler: Mihrimah Sultan, Rüstem Paşa, Kanuni Sultan Süleyman, Osmanlı, Hanedan, Evlilik

\section{ABSTRACT}

This paper studies the marriage of Mihrimah Sultan (1522-1578), the only daughter of Süleyman the Magnificent, in the context of Ottoman dynastic marriage politics. At the beginning, the Ottoman dynasty established marriage 
alliances with neighboring principalities and elites. In the fifteenth century, the number of concubines increased in dynastic reproduction and by the beginning of the sixteenth century, members of the dynasty stopped having legal marriages. During the sixteenth century, as the Ottoman dynasty preferred concubines to legally married wives, the royal daughters were married out to the promising governing elite. These marriages helped the career promotions of royal sons-in-law accelerate. In this context, Süleyman's daughter Mihrimah was married to Rüstem Pasha who had drawn the sultan's attention. Thanks to his marriage with Mihrimah, Rüstem's career accelerated and he quickly became the Grand Vizier. He was dismissed from the position for a while due to his involvement in the execution of Şehzade Mustafa by the sultan in 1553 but he was quickly restored to the position again. His marriage to Mihrimah helped Rüstem keep his power and prestige. This paper investigates the processes, stages and turning points of Mihrimah Sultan's marriage in light of existing historical sources. In particular, it discusses how Rüstem Pasha was selected among possible candidates as Mihrimah's husband, the couple's wedding ceremony and marriage life afterwards, Ayşe Hümaşah and other alleged children in this marriage, Mihrimah Sultan's life and influence in politics after the death of Rüstem Pasha in 1561.

Keywords: Mihrimah Sultan, Rüstem Pasha, Süleyman the Magnificent, Ottoman, Dynasty, Marriage

\section{EXTENDED ABSTRACT}

This paper studies the marriage of Mihrimah Sultan (1522-1578), the only daughter of Süleyman the Magnificent from his beloved consort and later wife, Hürrem Sultan (d. 1558), in the context of Ottoman dynastic marriage politics. It first discusses the Ottoman policy of marriage and reproduction from the early fourteenth century until the mid-sixteenth century. Then it goes on to analyze the marriage of Mihrimah Sultan with Rüstem Pasha (d. 1561) and contextualize it within the context of sixteenth-century Ottoman realities. In particular, it discusses how Rüstem Pasha was selected among possible candidates for being royal sonin-law, the couple's wedding ceremony and marriage life afterwards, Ayşe Hümaşah and other alleged children in this marriage, Mihrimah Sultan's life and influence in politics both during Rüstem Pasha's tenure as grand vizier and after his death in 1561.

At the beginning, the Ottoman dynasty established marriage alliances with neighboring Muslim principalities and Byzantine elites and it reproduced itself through these marriages. In the fifteenth century, the number of concubines increased in dynastic reproduction and by the beginning of the sixteenth century, members of the dynasty stopped having legal marriages. This transformation was also related to the dynasty's increasing prestige. During the sixteenth century, as the Ottoman dynasty preferred concubines to legally married wives, the royal daughters were married out to the promising governing elite. These marriages helped the career promotions of royal sons-in-law accelerate.

In this context, Süleyman's daughter Mihrimah was married to Rüstem Pasha, who succeeded in drawing the sultan's attention. Among other candidates, Rüstem seemed to be the best royal son-in-law for the sultan. This paper clearly shows that the alleged candidacy of Architect Sinan to marry Mihrimah did not have any space in historical sources and it was impossible, considering the dynastic marriage politics of the period. Rüstem was a devshirme 
boy educated in the Ottoman palace and raised to prominence thanks to his skills, service and loyalty. While he was a promising provincial governor, the sultan chose him as son-inlaw despite all accusations and alleged illnesses.

Following his marriage with Mihrimah, Rüstem's career accelerated and he quickly became the grand vizier in 1544. He was dismissed from the position for a while due to his involvement in the execution of Şehzade Mustafa by the sultan in 1553, but he was soon restored to the position again. Rüstem's marriage to Mihrimah helped him keep his power and prestige. During his career as grand vizier, the sultan withdrew from daily politics and left it completely to the grand vizier. According to contemporary observations, Rüstem enjoyed great power and acted as the sole decision maker in Ottoman domestic and foreign politics. While he was a skilled governor and successful grand vizier, Rüstem's power was mostly due to his loyal service to the sultan and his marriage to Mihrimah. When he was dismissed from his role for a short period, he was not forced to divorce Mihrimah like many dismissed statesmen. It was Mihrimah and probably his mother Hürrem as the most solid ground behind Rüstem's power and prestige. According to a Spanish account, when Mihrimah became very ill, c. 1553-54, Rüstem (and his brother Sinan Pasha) feared her death because they believed that all of their positions and powers depended on the life of this princess.

Mihrimah survived her husband, who died in 1561. She never married again, despite the existence of some rumors, but she continued to enjoy the wealth her husband left and was effective in Ottoman politics. She chose a promising son-in-law to marry her daughter Ayşe Hümaşah: Ahmed Pasha, who would become grand vizier for a short period of time. She left her daughter and grandchildren the significant wealth she and her husband had accumulated.

In short, this paper investigates the processes, stages and turning points of Mihrimah Sultan's marriage in light of existing historical sources. It analyzes her marriage in the context of changing Ottoman dynastic marriage politics in the sixteenth century. She was married to a provincial governor with devshirme origin, Rüstem Pasha, who would rise to become grand vizier quickly. Her marriage to this statesman played a key role in his prestige and power at a time when the Ottoman dynastic image was free from questions. 


\section{Giriş}

Kanuni Sultan Süleyman'ın yetişkin yaşa erişen çocuklarından tek kızı Mihrimah Sultan'ın hayatı hakkındaki bilgiler dönemin siyasi olarak etkin olan diğer şahsiyetlerine oranla hala yetersizdir. Hem babasının biricik kızı olarak birçok iltifata mazhar olmasına hem de siyasi olaylarda aktif roller üstlenmesine rağmen, Mihrimah'ın hayat hikayesi ya sadece ansiklopedik bilgilerle ya da romanlar için tahayyül edilmiş bazı hikayelere konu olmakla sınırlı kalmaktadır.' Süleyman'ın evrensel imparatorluk kurma idealiyle şekillenen bir dönemde doğan ve çocukluğunu geçiren Mihrimah'ın gençlik dönemi ve evliliği ise iddialı dış politikalar yerine barışçıl uzlaşılara dönülüp bürokratik büyümenin gerçekleştiği bir zamana tekabül etmiştir. Süleyman'ın en uzun süre sadrazamlığını yapan fakat aynı zamanda pek ihtilaflı bir imajı olan Rüstem Paşa ile evlenen Mihrimah, bir taraftan kocasının kariyerinde etkin bir rol oynamış diğer taraftan Rüstem Paşa ile birlikte birçok vakıf eseri bırakmıştır. Mihrimah'ın evliliği, hem 16. yüzyılda hanedanın gücünün evlilik yolu ile nasıl gösterildiğine hem de yükselmekte olan bir Osmanlı elitinin kariyerinin nasıl şekillendiğine işaret etmektedir.

Mihrimah Sultan'ın 1522 yılı içinde İstanbul'da doğduğu kaydedilirken doğum günü tam olarak bilinememektedir.2 Doğumu esnasında Süleyman'ın Rodos Seferi'nde olması muhtemeldir. Kendisinden bir yıl önce doğan Şehzade Mehmed'den sonra annesi Hürrem Sultan'ın Süleyman'a yeni bir çocuk doğurması Hürrem'in ileride ne kadar büyük bir güç sahibi olacağına da işaret etmekteydi. Nitekim Hürrem'in haremde giderek yükselen gücüne paralel olarak çocukları da daha fazla ön plana çıkmaya başladılar. ${ }^{3}$ Mihrimah'ın çocukluğu hakkında çok az şey kayda geçmiş olmasına rağmen hemen hemen zamanının çoğunu Eski Saray'da geçirmiş olduğu tahmin edilmektedir. Eski Saray II. Mehmed'in İstanbul'u fethinden hemen sonra şehrin ortasında inşa ettirmiş olduğu ilk saray olup, daha sonra Yeni Saray'ın inşası tamamlandığında Eski Saray sadece padişahın haremi olarak faaliyet göstermeye başladı. ${ }^{4}$ Hanedanın devamının sağlanmasının yanında bir eğitim programını da içeren Harem kurumu

1 Mihrimah üzerine yapılan bazı akademik çalışmalar için bkz. Nejat Uçtum, "Hürrem ve Mihrümah Sultanların Polonya Kıralı II. Zigismund'a Yazdıkları Mektuplar," Belleten 44/176 (1980), 697-715; Christine Isom-Verhaaren, "Süleyman and Mihrimah: The Favorite's Daughter," Journal of Persianate Studies 4/1 (2011), 64-85; Christine Isom-Verhaaren, "Mihrimah Sultan: A Princess Constructs Ottoman Dynastic Identity," Living in the Ottoman Realm: Empire and Identity, $13^{\text {th }}$ to $20^{\text {th }}$ Centuries içinde, ed. Isom-Verhaaren Christine and Schull Kent $\mathrm{F}$. (Bloomington: Indiana University Press, 2016), 150-66; Mustafa Kaçar, "Mihrimah Sultan," TDV İslam Ansiklopedisi, c. 30 (İstanbul: Türkiye Diyanet Vakfı, 2005), 39-40; Franz Babinger, "Mihr-i Māh Sulțān" Encyclopaedia of Islam, Second Edition, c. 7 (Leiden: Brill, 1993), 7.

2 A. D. Alderson, The Structure of the Ottoman Dynasty (New York: Oxford University Press, 1956), Tablo XXX, s. 251; Alan Fisher, "Süleymân and His Sons," Soliman Le Magnifique Et Son Temps: Actes du Colloque De Paris, Galeries Nationales Du Grand Palais, 7-10 Mars 1990 içinde, ed. Gilles Veinstein (Paris: Documentation française, 1992), 117-124.

3 Hürrem Sultan'ın biyografisi için bkz. Leslie P. Peirce, Empress of the East: How a European Slave Girl Became Queen of the Ottoman Empire (New York: Basic Books, 2017).

4 Gülru Necipoğlu, Architecture, Ceremonial, and Power: The Topkapi Palace in the Fifteenth and Sixteenth Centuries (New York, N.Y: Architectural History Foundation, 1991), 3-4. 
fiziksel olarak dışarı ile bağlantısı sınırlı olarak kadınların yaşadığı bir mekândı. ${ }^{5}$ Harem'deki eğitim programını takip ettiğini düşünürsek, Mihrimah'ın da burada Kur'an, ilmihal, kıraat ve kitabet gibi temel dersleri aldığını düşünebiliriz. Eğer yazdığı mektupları kendisinin kaleme aldığını varsayarsak okuma yazma ve edebi ifade konusunda iyi bir eğitim aldığı söylenebilir.6

Harem'de geçen çocukluk ve eğitim dönemlerinden sonra Mihrimah'ın, evlilik çağına geldiğinde, Rüstem Paşa ile evlenmesine karar verildi. Osmanlı hanedanının bir üyesi olarak Mihrimah'ın devşirme kökenli Rüstem Paşa ile evlenmesi ne anlama gelmekteydi? Süleyman hangi gerekçelerle Rüstem'i kendisine damat olarak seçmişti? Daha da önemlisi bu evlilik o dönemde nasıl yorumlandı ve nasıl algılandı? Bu ve benzer sorulara cevap arayacak olan bu çalışma, Kanuni Sultan Süleyman'ın tek kızı olan Mihrimah'ın evliliğini genel Osmanlı evlilik politikaları çerçevesinde inceleyecektir. Bir taraftan romanlarda ve popüler kitaplarda sıklıkla rastlanan ve sorgulanmadan kabul edilen bazı bilgiler sorgulanacak ve Mihrimah Sultan'ın evlilik tecrübesi kronolojik olarak irdelenecektir. İlk önce Osmanlı hanedanının 16. yüzyıla kadarki evlilik tecrübeleri incelenecek, sonrasında Mihrimah için damat seçimi ve Rüstem Paşa ile geçirdikleri evlilik yılları anlatılacaktır.

\section{Yüzyıl Ortalarına Kadar Osmanlı Evlilik Politikaları}

16. yüzyıla gelinceye kadar Osmanlı hanedanının erkek ve kadın üyelerinin evlilikleri, hanedanın prestiji ve toplum nezdindeki yerine paralel olarak birtakım dönüşümler geçirmiştir. Genel olarak hanedan evliliklerinde birtakım siyasi ve toplumsal uzlaşılar veyahut ittifaklar söz konusuydu. Osmanlı tarih kaynakları (her ne kadar 15. yüzyılın sonlarından itibaren ortaya çıkmış ve bazı noktalarda farklılaşıyor olsalar da) genel olarak ilk Osmanlıların çevredeki ileri gelen beylikler ve toplumsal önderler (mesela Sufi şeyhler) ile evlilik yoluyla ittifak kurduklarına işaret etmektedir.7 Osman Bey (ö. 1326), Şeyh Edebali'nin kızı Malhun Hatun ve Ömer Bey isminde bir kişinin kızı Mal Hatun ile evlenmiş; Orhan Bey (ö. 1362), Yarhisar Tekfurunun kızı olduğu söylenen ve asıl adı Holifera/Olivera olan Nilüfer Hatun, Bizans İmpara-

5 Leslie P. Peirce, The Imperial Harem: Women and Sovereignty in the Ottoman Empire (New York: Oxford University Press, 1993), 113-49.

6 Nejat Uçtum, “Hürrem ve Mihrümah Sultanların Polonya Kıralı II. Zigismund'a Yazdıkları Mektuplar”; Kaçar, "Mihrimah Sultan," 40; Necdet Sakaoğlu, Bu Mülkün Kadın Sultanları: Valide Sultanlar, Hatunlar, Hasekiler, Kadınefendiler, Sultanefendiler (Istanbul: Alfa Tarih, 2015), 254.

7 ilk dönem Osmanlı evlilikleri hakkında bilgi veren kaynaklar genellikle 15. yüzyılın sonlarında ortaya çıksa da ortak bazı bilgiler sunmaları bakımından bizim için hala değerlidir. Şu kaynakların sunduğu bilgiler özellikle önemlidir: Neşrî, Cihânnümâ, haz. Necdet Öztürk (ìstanbul: Çamlıca, 2008); Aşıkpaşazade, Osmanoğulları'nın tarihi: Tevârîh-i Âl-i Osmân, neşr. Kemal Yavuz ve M. A. Yekta Saraç (İstanbul: Gökkubbe, 2007); Oruç Bey, Oruç Bey Tarihi: Osmanlı Tarihi (1288-1502), neşr. Necdet Öztürk (İstanbul: Bilge Kültür Sanat, 2014); Dukas, İstanbul'un Fethi: Dukas Kroniği 1341-1462, çev. V. Mirmioğlu (İstanbul: Kabalcı, 2013),

8 Kaynakların farklı anlatılar sundukları meselelerden birisi Osman Bey'in evlendiği kadınlardır. Bu konuda bkz. M. Çağatay Uluçay, Padişahların Kadınları ve Kızları (İstanbul: Ötüken, 2011), 17; Peirce, The Imperial Harem, 32-34; İsmail Hakkı Uzunçarşılı, "Gazi Orhan Bey Vakfiyesi”, Osmanlı Hanedanı Üstüne Incelemeler: Seçme Makaleler Il içinde (İstanbul: Yapı Kredi Yayınları, 2012), 44. 
toru III. Andronikos'un kızı Asporça Hatun, Bizans İmparatoru VI. John Kantakuzenos'un kızı Theodora ve Eftandise Hatun isminde bir kadın ile evlenmiştir. ${ }^{9}$ I. Murad (ö. 1389), Rum asıllı Gülçiçek Hatun, Bulgar Kralı Şişman'ın kız kardeşi Tamara ve Paşa Melek Hatun ile evlenmiştir. ${ }^{10}$ Bunların dışında I. Murad'ın eşleri arasında Bizanslı V. Ioannes Paleologos'un (1341-1391) ailesinden biri, Köstendil Lordunun kızı ve Çandarlı ailesinden bir kız da zikredilmektedir. ${ }^{11} \mathrm{I}$. Bayezid'in (ö. 1403) eşleri arasında ilk olarak Germiyanoğlu Süleyman Şah'ın kızı Devletşah zikredilmektedir. Devletşah soyu itibariyle aynı zamanda anne tarafından Celaleddin Rumi'nin soyundan gelen Mutahhare Hatun'un kızıdır. Bundan başka Bayezid, Sırp Kralı I. Lazar'ın kızı Maria Despina Hatun ile evlenmiştir ki bu evliliği sebebiyle birçok eleştirinin hedefi olmuştur. ${ }^{12}$

Buraya kadar baktığımızda ilk Osmanlı beyleri 14. yüzyılda komşu beylikler, Bizans, Balkan hanedanları ve Anadolu'da ileri gelen tasavvuf ve ulema büyüklerinin kızları ile evlenmişlerdir. Aynı şekilde hanedana mensup kızlar da bu gruptan komşu beyliklerin beyleri ve prensleri ve de Anadolu'nun toplumda ileri gelen kişileri ile evlendirilmişler fakat gayrimüslimlere evlilik yolu ile verilmemişlerdir. İslam hukukunda da altyapısı olan bu eğilim ile Osmanlı hanedan evlilikleri komşu beylik hanedanları ile ittifak kurma işlevi görmekteydi. İlk dönem Osmanlı hanedan meşruiyetinin zayıflı̆ını göz önünde bulundurursak, hanedanlar arası ittifak siyasi başarı ve süreklilik açısından önemliydi.

Fakat bu eğilim 15. yüzyılda değişmeye başladı ve Osmanlı sultanlarının artık kendileri için cariyeleri tercih ettikleri görülür hale geldi. Osmanlı sultanlarının resmi evlilikler yaptıkları kadınlar yerine cariyeler aracılığı ile hanedan soyunun devamını sağlamasının sebepleri olarak iki husus ileri sürülmektedir. İlk olarak, Ankara Savaşı'nda I. Bayezid ile Sırp eşinin Timur'a esir düşmesi ve Bayezid'in gözü önünde eşinin tahkir edilmesi ve bundan dolayı soylu kadınlarla evlenmeyerek bir daha böyle bir duruma düşmek istemedikleri düşünülmüştür. Yalnız, Osmanlıların sadece olası yenilgileri düşünerek evlilik politikalarını belirlemiş olmaları pek muhtemel değildir. ${ }^{13}$ İkinci olarak, Osmanlıların İslam hukukuna göre resmi evlilikte damadın geline verdiği mehri vermemek için hür kadınlarla evlenmek yerine cariyeleri tercih ettikleri iddia edilmektedir. İslam aile hukukuna göre, nikah akdi ile evlenmek kadınlara mehir, miras vb. bazı haklar getirirken, köle statüsünde bulunan cariye kadınlar kendilerine sahip olan erkeklerden bu hakları ancak sınırlı durumlarda ve ancak çocuk sahibi olmalarında elde edebiliyorlardı. Fakat, aşağıda görüleceği üzere Osmanlı sultanları resmi evliliklerinde yüklü miktarda mehir vermekten çekinmemekteydiler.

Muhtemelen, Osmanlıların başlangıçta hür ve soylu kadınlar ile evlenirken 15. yüzyılda giderek cariyelere yönelmeleri Osmanlı hanedanının giderek yükselen prestiji ile alakalıydı.

9 Uluçay, Padişahların Kadınları ve Kızları, 18-20; Peirce, The Imperial Harem, 34-37.

10 Uluçay, Padişahların Kadınları ve Kızları, 21-22; Peirce, The Imperial Harem, 36-37.

11 Sakaoğlu, Bu Mülkün Kadın Sultanları, 64-66.

12 Uluçay, Padişahların Kadınları ve Kızları, 23-25; Peirce, The Imperial Harem, 40; Sakaoğlu, Bu Mülkün Kadın Sultanları, 75-90.

13 Peirce, The Imperial Harem, 38. 
Nitekim II. Mehmed'den (ö. 1481) itibaren sultanlar birkaç istisna dışında sadece cariyeleri haremlerine dahil etmişler ve başlangıçta zayıf prestijden kaynaklanan ittifak kurmak amacıyla geliştirdikleri evlilik politikalarını kendi kontrollerinde dönüştürmeye başlamışlardı. Elbette resmi evlilikler 15. yüzyılda tamamen yok olmadı (mesela II. Murad Sırp Kral George Brankoviç ve Irene Komnenos'un kızı Mara ile ve II. Bayezid Dulkadiroğulları'ndan Ayşe Hatun ile evlenmişti) ${ }^{14}$ fakat yüzyılın sonunda padişahların resmi evlilik yapmak yerine cariyeleri tercih etmeleri artık yerleşmiş bir olgu olmuştu. ${ }^{15} \mathrm{II}$. Mehmed'in şehzadelerinin anneleri (Gülbahar Hatun, Gülşah Hatun, Çiçek Hatun, ve Mora Despotu Demetrius'un kızı Helene) cariye olarak padişahın haremine dahil oldular. ${ }^{16}$

II. Mehmed'in benimsediği bu yeni tercih II. Bayezid (ö. 1512) ve I. Selim (ö. 1520) tarafından da benimsendi ve bu yeni eğilim Süleyman devrinde de varlığını sürdürdü. ${ }^{17}$ Bayezid, Selim ve Süleyman (ö. 1566) döneminde hanedan cariyelerle varlığını sürdürürken hür kadınlarla evlilik yapmak neredeyse unutulmuş durumdaydı. Bu durum Osmanlıların İstanbul fatihi II. Mehmed dönemi ile birlikte sürekli artan prestijinin bir yansımasıydı. Bir taraftan Osmanlı topraklarının genişlemesi sonucu çevrede ittifak kurmak için Osmanlılardan üstün veya denk beylik veya emirlik kalmamıştı diğer taraftan da Osmanlı sultanları kendilerini giderek 15. yüzyılın ilk yarısına kadar ileri gelen toplumsal grupların üstünde konumlandırmaktaydılar. Buna paralel olarak sultanlar evlilikleri kendileri için değil ama hanedanın kızlarını yükselmekte olan yönetici eliti inşa etmek ve onları kendilerine bağlamak amacıyla kullanmaya başladılar.

Bayezid ve Selim döneminde hanedana damat olanlardan sadece Hersekzade Ahmed, Dukaginzade Ahmed ve Yunus Paşalar vezir statüsüne erişmişken Süleyman dönemindeki bütün hanedan damatları vezirliğe eriştiler. ${ }^{18}$ Aslında Bayezid ve Selim döneminde vezirliğe ulaşmış üç vezirin bu makamlara gelmesi onların damat olmasından ziyade aile kökeni olarak Balkan aristokrat arka planına sahip olmaları ile alakalıydı. ${ }^{19}$ Fakat Süleyman döneminde hanedanın bütün damatlarının vezirliğe ulaşmış olması bu dönemde hanedanın hanım sultanlarının evliliğinin belirli bir elit adayını yüceltme politikası olarak kullanıldığını göstermektedir. Vezirlerden Ferhad, Lütfi ve Kara Ahmed Paşalar sırasıyla sultanın kız kardeşleri Beyhan Sultan, Şah Sultan ve Fatma Sultan ile evlenirken, Rüstem Paşa, sultanın kızı Mihrimah Sultan ile,

14 Uluçay, Padişahların Kadınları ve Kızları, 35 ve 43; Sakaoğlu, Bu Mülkün Kadın Sultanları, 130-40 ve 182-88.

15 Ceneviz kökenli olup 15. yüzyııın sonlarında sarayda içoğlanı olan ve daha sonra Osmanlı topraklarından Avrupa'ya kaçan Giovanantonio Menavino sultanların hiç evlilik yapmadıklarını söylemektedir. Krş. Peirce, The Imperial Harem, 30.

16 Uluçay, Padişahların Kadınları ve Kızları, 38-41.

17 Peirce, The Imperial Harem, 65-66.

18 Peirce, The Imperial Harem, 66.

19 II. Bayezid dönemindeki vezirlerin ve hanedana damat olanların aristokratik kökenleri hakkında bkz. Heath W. Lowry, The Nature of the Early Ottoman State (Albany: State University of New York Press, 2003), böl. 7; Heath W. Lowry, Hersekzâde Ahmed Paşa: An Ottoman Stateman's Career \& Pious Endowments (Istanbul: Bahçeşehir University Press, 2011); Hedda Reindl, Männer um Bāyezīd: eine prosopographische Studie über die Epoche Sultan Bāyezīds II. (1481-1512) (Berlin: K. Schwarz, 1982). 
Sokollu Mehmed Paşa ise bir sonraki sultan olan II. Selim'in kızı İsmihan Sultan ile evlendiler. ${ }^{20}$ Büyük bir ihtimalle Süleyman kız kardeşlerini veya kızı ve kız torunlarını devşirme kökenliler ile evlendirmeyi tercih ederek onlar arasından seçtiklerini bu evlilikler yoluyla desteklemek istemişti ve onun saltanatı döneminde hanedana damat olanları vezirlik payesine kadar yükseltmişti. Bu bağlamda Süleyman'ın tek kızı Mihrimah ile evlenecek kişi de sultanın gözüne girmiş ve kariyeri giderek yükselecek birisi olacaktı.

\section{Mihrimah için Damat Adayı: Rüstem Paşa}

1539 yılında Mihrimah 17 yaşı civarında iken Rüstem Paşa ile evlendi. 0 sıralar Diyarbekir Beylerbeyi olan Rüstem Paşa ise 30'lu yaşlarının sonlarındaydı. Süleyman'ın hem aradaki bu kadar yaş farkını göz ardı etmesi hem de tek kızını üzerinde çağdaş kaynaklar tarafından pek de yakışıklı olmadığı ve hatta çirkin olduğu konusunda ittifak ettiği Rüstem ile evlendirmeye karar vermesi eleştiri konusu olmuştur. Anlaşılan Süleyman kızını Rüstem ile evlendirmeye çok önceden kesin olarak karar vermişti ve her türlü itiraza rağmen bu kararında ısrar etti. O zamana kadarki Osmanlı hanedan evliliklerini ve bu konudaki tercihlerdeki dönüşümü göz önünde bulundurursak, bu evliliğin siyasi birtakım sembolik anlamları olduğunu söyleyebiliriz. Bu çerçevede, Mihrimah'ın evliliğinin komşu bir beylik veya hanedan ile ittifak amacı olmaktan ziyade sultanın bir vezir adayının kariyerini yükseltme işlevi görmesi beklenmektedir. Bu açıdan Mihrimah'ın evleneceği damat adayı olarak Rüstem'in seçilmesi ve sonrasında Rüstem'in kariyerinin izlediği süreç Osmanlı hanedanının evlilik politikasındaki duruma ışık tutmaktadır.

Bu noktada vurgulanması gereken önemli bir husus ise Mihrimah ile evlenmesi muhtemel adayların arasında Mimar Sinan'ın olduğu fikrinin gerçeği yansıtmadığı ve hatta bu ihtimalin mümkün olmadığıdır. Halihazırda birçok modern edebi ve popüler eserde Mimar Sinan'ın Mihrimah'a aşık olduğu ve aşkının sembolü olarak Mihrimah adına İstanbul'un iki tarafında, Üsküdar ve Edirnekapı'da iki zarif cami ve külliye inşa ettiği iddiası çokça zikredilmektedir. ${ }^{21}$ Aslında bu düşünce ilk defa 1972'de Sinan üzerine Arthur Stratton tarafından yazılan biyografide dile getirilmişti. ${ }^{22}$ Burada, Sinan'ın Mihrimah'a olan aşkının Edirnekapı'daki camide sembolik olarak ifade edildiği iddia edilirken herhangi bir öyküsel arka plan verilmemiştir. Dönemin kaynaklarından

20 Peirce, The Imperial Harem, 66-68; Uluçay, Padişahların Kadınları ve Kızları, 31-33. İbrahim Paşa'nın evlendiği kişinin Süleyman'ın kız kardeşlerinden biri olarak Hatice Sultan olduğu tartışmalıdır. İ. Hakkı Uzunçarşılının dikkat çekmesinden sonra Ebru Turan kesin olarak İbrahim'in önceki efendisi İskender Paşa'nın torunu Muhsine isminde biri ile evlendiğini ortaya koymaktadır. Bkz. İsmail Hakkı Uzunçarşılı, “Kanunî Sultan Süleyman'ın Vezir-i Âzamı Makbûl ve Maktûl İbrahim Paşa Padişah Dâmadı Değildi”, Belleten 39/114 (1965): 355-64; Ebru Turan, “The Marriage of Ibrahim Pasha (ca. 1495-1536): The rise of Sultan Süleyman's favorite to the grand vizierate and the politics of the elites in the early sixteenth-century Ottoman Empire", Turcica 41 (2009), 3-36. Bu dönemlerdeki soy ağaçları ve hanım sultanların evlilikleri için bkz. Alderson, The Structure of the Ottoman Dynasty, Tablolar XXVIII, XXIX, XXX ve XXXI.

21 Mesela bkz. Muhterem Yüceyılmaz, Has Bahçenin Gonca Gülü: Mihrimah Sultan (İstanbul: Nesil, 2008); Turan Oflazoğlu, Sinan (Ankara: Kültür ve Turizm Bakanlığı Yayınları, 1988).

22 Arthur Stratton, Sinan (New York: Charles Scribner's Sons, 1972). 
da herhangi bir destek gösterilmeden ileri sürülen bu iddia tamamen kurgusal bir fanteziden ibaret olup daha sonraki bazı çalışmalarda da sorgulanmadan kabul edilmiştir. ${ }^{23} \mathrm{Hem}$ Sinan'ın hayatını ve kariyerini hem de hanedanın evlilik politikalarını izlediğimizde bu fikrin tamamen hayal ürünü olduğu kolayca anlaşılabilir. Zira Mihrimah evlilik çağına geldiğinde, Sinan henüz dikkat çekmeyi tam olarak başaramamıştı. Ağırnas doğumlu olup devşirme usulü ile kapıkullarına dahil edilmiş olan Sinan o zamanlar en azından 50 yaşının üstündeydi. Sinan'ın kariyerindeki en kritik dönüm noktası, 1538 yılındaki Karaboğdan Seferi esnasında vezir Lütfi Paşa'nın tavsiyesi ile Prut nehri üzerine ordunun geçmesi için kısa sürede bir köprü inşa etmesi ve bu sayede seferden döndükten sonra mimarbaşı olarak tayin edilmesiydi. ${ }^{24} \mathrm{Bu}$ aşamadan sonra Sinan yükselmeye başlamış ve başta hanedan olmak üzere ileri gelenlerin vakfettiği yapıları inşa etmeye başlamıştır. Fakat 1530'ların sonlarında kariyerinin başında olan bir kişi olarak Sinan hanedana damat adayları arasında düşünülmemekteydi. Ayrıca, onun Mihrimah'ı görüp aşık olması da hem kaynaklar tarafından desteklenmemekte hem de teorik olarak mümkün görünmemektedir. Zira dönemin mahremiyet kuralları ve hanedan üyelerinin dışarı ile bağlantısı çerçevesinde haremdeki kadınları dışarıdan bir erkeğin görmesi pek olası değildir. Hatta 1560 yılında Venedikli balyos Marino di Cavalli, İslam hukukuna göre caiz olmasına rağmen Rüstem ile kayınvalidesi olan Hürrem Sultan'ın bile yüz yüze hiç konuşmadıklarını aktarmaktadır: "Rüstem Paşa... kayınvalidesinin [yani Hürrem Sultan'ın] gözdesiydi, fakat [Hürrem] onu hiç görmemişti (zira Türkler arasında kadınların kocaları ve babalarından başka erkeklerle görüşmeme adeti vardı)."25 Dolayısıyla, Sinan'ın Mihrimah'a aşık olabilmesi için onu görmesi bile mümkün değildi. Hatta daha sonrasında Mihrimah Sultan için inşa edilen camilerin yapım süreçleri için Sinan ile görüşmeleri Mihrimah adına ya vekili olarak Rüstem Paşa ya da kethüdası yapmaktaydı. ${ }^{26}$

Mihrimah ile evlendirilmeye karar verilen kişi Rüstem Paşa'ydı. Rüstem Saraybosna yakınlarında bir Hırvat köyünde domuz çobanlığı yapan küçük bir çocuk iken devşirilmiş, Galatasaray'da bir süre eğitim gördükten sonra Enderun'a içoğlanı olarak alınmıştı. ${ }^{27}$ Çağdaş gözlemciler tarafından keskin zekası ve hırslı karakteri vurgulanan Rüstem, kısa sürede kendisini gösterdi ve Hasoda'nın en prestijli makamlarından olan Silahdar Ağa rütbesine erişti. Rüstem 1526'da Mohaç Seferi'nden dönerken Enderun'dan Mîrâhur-ı Evvel olarak tayin edil-

23 Sinan'ın Mihrimah'a olan aşkını konu alan edebi eserleri inceleyen akademik bir çalışma için bkz. Simge Özer Pınarbaşı, “Mimar Sinan'ı Romanlarla Tanımak," Art Sanat 8 (2017), 405-423.

24 Gülru Necipoğlu, The Age of Sinan: Architectural Culture in the Ottoman Empire (Princeton: Princeton University Press, 2005), 128 ve 133-35.

25 "Rustan-pascià .... l'essere stato favorito da sua suocera, sebbene non lo vede mai (usando così i Turchi, che le donne loro non vedano altri che li mariti e padri loro)..." Bkz. Marino Cavalli, "Relazione dell'Impero Ottomano di Marino Cavalli, stato bailo a Costantinopoli nel 1560", Eugenio Albèri (ed.), Relazioni degli Ambasciatori Veneti al Senato, ser. III, c.1 (Firenze: Tipografia e Calcografia all'Insegna di Clio, 1840), 295.

26 Necipoğlu, The Age of Sinan, 301 ve 305-14.

27 Rüstem'in hayatı hakkında bkz. Şinasi Altundağ ve Şerafettin Turan, "Rüstem Paşa”, İslam Ansiklopedisi, c. 9, (İstanbul: Milli Eğitim Bakanlı̆ı, 1993), 800-802; Christine Woodhead, "Rüstem Pasha", Encyclopaedia of Islam, Second Edition, c. 8 (Leiden: Brill, 1995); Erhan Afyoncu, "Rüstem Paşa", TDV İslam Ansiklopedisi (İstanbul: Türkiye Diyanet Vakfı, 2008), 288-290; Zahit Atçıl, "State and Government in the Sixteenth Century Ottoman Empire: The Grand Vizierates of Rustem Pasha (1544-1561)" (Doktora Tezi, The University of Chicago, 2015). 
miş ve bundan sonra Bîrûn'da görev yapmaya başlamıştır. 1534 yılında Diyarbekir Beylerbeyi oldu ve burada görev yaparken Mihrimah Sultan ile evlendirilmeye karar verildi.

Süleyman'ın Mihrimah'ı Rüstem Paşa ile evlendirmeye ne zaman karar verdiği kesin değildir. Venedik balyosu Bernardo Navagero'ya göre, Rüstem tek aday da değildi. Mihrimah'ın annesi Hürrem Sultan kızını daha yakışıklı olduğu için Mısır Beylerbeyi Davud Paşa ile evlendirmek istiyordu. ${ }^{28}$ Fakat Mustafa Âlî’ye göre, padişah, henüz sarayda içoğlanı olduğu zamanda gözüne giren Rüstem ile kızını evlendirmeyi uzun bir zamandır düşünmekteydi. ${ }^{29}$

Navagero'nun aktardığına göre, bir gün Enderun'da diğer içoğlanları ile birlikte sultana eşlik ederlerken sultanın elinde bulunan bir şey pencereden aşağı düşer. Diğer içoğlanları onu getirmek için merdivenlere ve kapılara koşarlar fakat Rüstem pencereden aşağı atlar ve herkesten önce düşen şeyi alır getirir. Bu sayede sultanın gözüne girer. ${ }^{30}$ Bu hikâyenin sıhhati hakkında şüpheler tamamen giderilmemiş olsa da o dönemde Rüstem ile sultanın arasındaki yakınlığı göstermesi bakımından önemlidir. Nitekim Rüstem'in sultan ile yakınlığı Enderun'dan sonra da devam etmiştir. 1534'te Venedik balyosu Daneillo de' Ludovisi'nin raporuna göre, Rüstem ismindeki genç ve becerikli mîrâhur o zamanlar sultan ile yakınlık kurmuştu. Sultan da zekasından dolayı onunla konuşmayı ve onu dinlemeyi istiyordu. 0 vakit (Irakeyn Seferi sebebiyle) Halep'te bulunan Sadrazam İbrahim Paşa bu yakınlıktan endişe etmeye başlamış ve Rüstem'i Anadolu'da uzakta bir göreve tayin etmişti. Sultandan uzaklaşmak istemeyen Rüstem, bu isteğini sultana bildirince sultan da "ibrahim gelince, seni yeniden yakınıma aldırmaya çalışacağım" diye karşılık vermişti. ${ }^{31}$

Sultanın kızını Rüstem Paşa ile evlendirmek istediğini ilan etmesi ile Rüstem'in aleyhinde bir karalama kampanyası başladı. Tarihçi Mustafa Âlî̀nin aktardığına göre Rüstem'in cüzzam hastalığına yakalanmış olduğu ve hastalığın belirtilerinin cildinde görülmeye başlandığı şeklinde bir dedikodu yayıldı. ${ }^{32}$ Navagero ise bu dedikoduyu sultanın saygıdeğer Yahudi hekimi Moses Hamon aracığıyla yayan kişinin kızını Mısır Beylerbeyi ile evlendirmeyi düşünen Hürrem Sultan olduğunu ifade etmektedir. ${ }^{33}$ Sultan bu dedikodunun yayılmasından endişe duy-

28 Bernardo Navagero, "Relazione dell'Impero Ottomano del Clarissimo Bernardo Navagero, Stato Bailo a Costantinopoli Fatta in Pregadi nel Mese di Febbrajo del 1553", Relazioni degli Ambasciatori Veneti al Senato, ed. Eugenio Albèri, III, v.1 (Firenze: Tipografia e Calcografia all'Insegna di Clio, 1840), 99. Tarihçi Mustafa Âlî, Davud Paşa hakkında "kemâl-i emânet ve istikamet üzere hükümet" eden biri olarak bahsetmekte ve vezirlik rütbesi ile Mısır Beylerbeyi olduğunu ve yol kesen haramilerin saldırısı sonucu öldüğünü aktarmaktadır. Bkz. Mustafa Âlî, Künhü'l-ahbâr: Dördüncü Rükn, Osmanli Tarihi (Ankara: TTK, 2009), 363b.

29 Mustafa Âlî, Künhü'l-ahbâr, 358a-b.

30 Navagero, "Relazione", 98.

31 Daniello de' Ludovisi, “Relazione dell'Impero Ottomano Riferita in Senato dal Secretario Daniello de' Ludovisi, a di 3 Giugno del 1534", Relazioni degli Ambasciatori Veneti al Senato, ed. Eugenio Albèri, III, v.1 (Firenze: Tipografia e Calcografia all'Insegna di Clio, 1840), 12.

32 Mustafa Âlî, Künhü'l-ahbâr, 358b.

33 Navagero, "Relazione”, 99. Navagero dedikodunun Rüstem'in firengi/syphilis (Navagero'nun ifadesi ile mal francese) hastalığına yakalandığıı söylemektedir. Muhtemelen Navagero iddia edilen hastalığın ismini yanlış anladı veya Mustafa Âlî dedikoduyu biraz daha yumuşak bir şekilde aktarmaya çalıştı. 
muş ve kendisine damat olarak seçtiği Rüstem'in hakikaten cüzzamlı olup olmadığının nasıl anlaşılabileceği konusunu sarayın hekimbaşısı ile istişare etmişti. Hekim de cüzzamlı hastaya bit/kehle yaklaşmayacağını söyleyince sultan, Mehmed isimli saray hekimlerinden biri ile bir hazinedarı Diyarbekir'e gönderdi. Hekim ve hazinedar, Rüstem'e haber vermeden üstünü ve elbiselerini aniden ('ale'l-gafle) aradılar. Rüstem'in elbiselerini normalden çok sık değiştirme adeti olduğu ve temizliğe çok dikkat ettiği göz önünde bulundurulursa bit bulmak neredeyse mümkün değildi. Fakat şans eseri hazinedar bir bit buldu, Rüstem endişe ile bakarken hekim gülümsedi ve paşayı tebrik ederek padişaha damat olacağı müjdesini verdi. Bit sayesinde Rüstem'in cüzzamlı olmadığı ispatlanmış oldu ve Mihrimah ile evlenmesi için herhangi bir engel artık kalmadı. Rüstem bu müjde üzerine hazinedara 1000 sikke altın hediye, hekime de sınırsız paralar ve hediyeler verdi. ${ }^{34}$ Bu olaydan sonra Rüstem Paşa için kehle-i ikbâl künyesi verilmiş ve bu meseleye dair şu beyit yazılmıştır:

Olıcak bir kişinin bahtı kavî tâli i yâr

Kehlesi dahi mahallinde anıñ işe yarar. ${ }^{35}$

\section{Düğün (1539)}

Rüstem'in Mihrimah ile evlenmesinin önünde bir engel kalmayınca Rüstem'in yükselmesi de hızlandı. Kısa sürede önce Anadolu Beylerbeyliğine, sonra da dördüncü vezirliğe yükseldi. ${ }^{36}$ Aynı yıl sonuna doğru 15-28 Receb/26 Kasım-4 Aralık 1539 tarihleri arasında Şehzade Bayezid ve Cihangir'in sünnet düğünleri esnasında Mihrimah ile Rüstem'in nikah akdi de gerçekleşti. ${ }^{37}$ Sünnet düğünü ve nikah için soğuk havanın ve belki yağışın muhtemel olduğu bir zamanın seçilmiş olması garip durmaktadır. Fakat 1539'un yaz aylarında veba salgını -ve bu salgında Sadrazam Ayas Paşa'nın vefat etmesi- sebebiyle düğün için vebanın nispeten yavaşladığı kışa doğru bir vakit seçilmişti. ${ }^{38}$

Her ne kadar yaklaşık aynı uzunlukta ve benzer şekilde eğlenceler düzenlenmiş olsa da 1524'teki İbrahim Paşa'nın düğünü ve 1530'daki şehzadelerin sünnet düğünü merasimleri

34 Mustafa Âlî, Künhü'l-ahbâr, 358b-59. Rüstem Paşa hekime daha sonra Suriye'de 40000 akçelik bir zeamet tayin etmişti. Tarihçi Mustafa Âlî, 970/1562'de Suriye'de bu olayın içinde yer alan hekim ile karşıllaştığını ve bu hikâyenin sıhhatini hekimden bizzat tetkik ettiğini ifade etmektedir.

35 Ahmet Osmanzâde Taib, Hadikatü'l-Vüzerâ (Istanbul: Ceride-i Havadis Matbaası, 1271), 29; İsmail Hami Danişmend, Izahlı Osmanlı Tarihi Kronolojisi (İstanbul: Türkiye Yayınevi, 1947), II: 248.

36 Mustafa Çelebi Celâlzâde, Geschichte Sultan Süleymān Kạnnūnīs von 1520 bis 1557, oder, Țabakāt ül-Memālik ve Derecāt ül-Mesālik, ed. Petra Kappert (Wiesbaden: Steiner, 1981), 297a-298b; Mustafa Âlî, Künhü'l-ahbâr, 308a-11.

37 Celâlzâde, Țabakāt, 337a-340b; Mustafa Âlî, Künhü'l-ahbâr, 312a.

38 Veba ihtimalinden dolayı sünnet ve nikah için Kasım ayının seçilmiş olmasına dikkat çeken makale için bkz. Zeynep Yelçe, "Evaluating Three Imperial Festivals: 1524, 1530, 1539", Celebration, Entertainment and Theater in the Ottoman World içinde, ed. Suraiya Faroqhi ve Arzu Öztürkmen (London: Seagull Books, 2014), 77. Ayrıca vebanın salgın zamanları hakkında ve genel olarak salgının yaz aylarında hızlanıp kış aylarında yavaşlaması hakkında bkz. Nükhet Varlik, Plague and Empire in the Early Modern Mediterranean World: The Ottoman Experience, 1347-1600 (New York, NY: Cambridge University Press, 2015), 18 ve 173. 
ile mukayese edilince 1539 sünnet düğünü ve nikah merasiminin daha sönük olduğuna dair bir kanı oluşmuştur. ${ }^{39}$ Muhtemelen Süleyman'ın saltanatının ilk on beş yılındaki hırslı genişlemeci politika bağlamında gerçekleşen ilk iki düğün/sünnet yapılan eğlence ve kutlamalarla kaynaklara daha görkemli birer olay olarak yansımıştı. Fakat özellikle 1530'ların ortalarından itibaren giderek daha barışçıl ve realist politikalar nedeniyle 1539'daki düğün sanki daha sade bir kutlama gibi algılanmıştı. ${ }^{40}$

Nikah akdinin kaydı sicile şu şekilde yazılmıştır:

Sebeb-i tahrîr budur ki Cenâb-ı Dürret-i İklîlü'l-iffe Hazret-i Sultân Mihrimâh bt. Hazret-i Sultân-ı A'zam Süleymân Han kıbelinden 'akd-i nikah için Sünbül Ağa b. Abdurrahman ve Bilal Ağa b. Abdurrahmân şehâdetleriyle vekâleti sâbit olan Selmân Ağa b. Abdülmu'în ve Cenâb-ı Âli Hazret-i Rüstem Paşa b. Abdurrahmân kıbelinden akd-i tezevvüc için Mehmed b. Süleymân ve Mustafa b. Ömer şehâdetleriyle vekâleti sâbit olan Hazret-i Süleymân Paşa meclis-i şer'e hâzırân olup mezkûr Selmân Ağa hazret-i müvekkile-yi merkûmeyi zikr olunan vekâleti hükmü ile mûmâ-ileyh Rüstem Paşa hazretlerine yüz bin tâmmü'l-vezn filori-i sultânî mehr-i müeccel üzere tezvîc ve nikâh idüb ve müşârun-ileyh Süleymân Paşa dahi hazret-i müvekkil-i merkûm için zikrolunan mehr üzere akd-i mezbûrı kabul ettikden sonra şerâit-i îcâb ve kabûl-i akd-i nikah kemâ yenbağî ri'âyet ve müeddâ kılındıkdan sonra bu hurûf tahrîr olundu. Fîyevmi'l-Cum'a 23 akîbe's-salat min Recebi'l-Mürecceb 946 [9 Aralık 1539].41

Nikah kaydına yansıyan bilgilere baktığımızda, akdin gerçekleştiği anda ne Mihrimah ne de Rüstem'in hazır bulunmadığı anlaşılmaktadır. Onları kendilerinin yerine tayin edilen vekiller temsil etmiş ve böylece nikah kıyılmıştı. Özellikle İslam kültüründe gelinlerin nikah akitleri esnasında vekillerinin yer alması çok yaygın olmakla birlikte Osmanlı devletinde vezir, kazasker, beylerbeyi gibi elitlerin nikahlarında damatların da vekilleri ile temsil edilmeleri yaygın bir durumdu. ${ }^{42}$ Bu bağlamda Mihrimah ve Rüstem'in nikahlarında kendileri yerine vekillerinin yer alması şaşırtıcı değildir.

Fakat nikah kaydında dikkat çeken asıl önemli husus nikah için tayin edilen mehir miktarıdır. İslam hukukuna göre, nikah esnasında belirlenen ve damadın geline o anda verdiği (muaccel) veya daha sonra vermeyi taahhüt ettiği (müeccel) maddi miktar anlamında kullanılan mehir, nikah akdinin en önemli sonuçlarından biridir. Ayrıca miktarın büyüklüğü ve niteliği da-

39 Bu üç merasimin mukayesesi için bkz. Yelçe, "Evaluating Three Imperial Festivals".

40 Kaya Şahin, "Staging an Empire: An Ottoman Circumcision Ceremony as Cultural Performance", The American Historical Review 123/2 (2018): 463-92.

41 İstanbul Şer'iyye Sicilleri Evkâf-ı Hümayun Müfettişliği, def. No: 2, s. 89. Buradan aktaran M. Akif Aydın, “Osmanlı Hukukunda Nikah Akitleri", Osmanlı Araştırmaları 3 (1982), 5.

42 M. Akif Aydın, Osmanlı Aile Hukuku (İstanbul: Klasik, 2017), 62. 
madın sosyal ve ekonomik statüsünü gösterdiği gibi geline verilen önemi de ifade etmektedir.43 Burada Rüstem Paşa'nın Mihrimah'a vermeyi taahhüt ettiği mehir miktarının 100.000 altın sultani olarak belirlendiğini anlıyoruz. Peki bu miktar ne ifade etmekteydi? illk önce Mihrimah ile Rüstem'in nikahlarından yaklaşık beş yıl önce kıyılan Sultan Süleyman ile Hürrem Sultan'ın nikahlarında da 100.000 altın sultani belirlendiği anlaşılmaktadır. Her ne kadar elimizde bu nikahın kaydı olmasa da daha sonraki bir gözlem bize ışık tutmaktadır. Nurbanu Sultan ile evlenen II. Selim babasından daha fazla mehir vermek istemiş ve mehri 110.000 altın sultani olarak belirlemişti. Aynı kayıtta Süleyman'ın Hürrem ile nikah akdinde mehrin 100.000 altın sultani olarak belirlendiği ifade edilmektedir. ${ }^{44}$ Anlaşılan Süleyman'ın vermeyi taahhüt ettiği mehir bir standart oluşturmuş ve sonra hanedan evliliklerinde mukayese için ölçü olmuştur.

Hanedanın kızları evlendirilince damadın yanına gitmeleri âdet olduğu fakat Mihrimah Sultan'ın bu âdete uymayıp İstanbul'da kalması için Rüstem Paşa'nın İstanbul'da bir göreve terfi ettirildiği ve bundan sonra da hanedanın kızları ile evlenenler için terfi ettirilmenin yeni bir âdet haline geldiği modern çalışmalarda sıklıkla iddia edilmektedir. ${ }^{45}$ Genel olarak hanedandan bir kız ile evlenecek kişilerin Osmanlı sistemi içinde daha iyi bir konuma gelmesi beklenen bir şeydi elbette. Fakat bu âdetin Mihrimah Sultan-Rüstem evliliği ile başladığı iddiası pek gerçeği yansıtmamaktadır. Zira Rüstem Paşa'nın İstanbul'da bir makama getirilmesi kronolojik olarak düğünden daha önce gerçekleşmişti.

Rüstem Paşa Diyarbekir Beylerbeyliği görevinde iken Mihrimah Sultan ile evlendirilmeye karar verilmişti. 1538 yılında Osmanlı ordusu Karaboğdan Seferi'ne çıkmak üzere iken vezir Mustafa Paşa ölür (10 Safer 945/8 Temmuz 1538) ve onun yerine Rumeli Beylerbeyi Mehmed Paşa getirilir. Bu vesile ile Anadolu Beylerbeyi Hüsrev Paşa, Rumeli Beylerbeyi olurken Diyarbekir Beylerbeyi Rüstem Paşa da Anadolu Beylerbeyliğine getirilir. ${ }^{46}$ Rüstem Paşa'nın yeni görev yeri artık Kütahya olmuştur ve bu yeni terfi ile birlikte sefere katılmak üzere çağrılır. Diyarbekir'den ayrılıp Anadolu'yu kat edip orduya yetişene kadar epey zaman geçer ve orduyu ancak seferden dönerken Edirne'de yakalayabilir. ${ }^{47}$ Ordunun İstanbul'a ulaşmasından (5 Receb 945/27 Kasım 1538) sonra Rüstem Paşa Kütahya'ya ancak gider. ${ }^{48}$ Fakat altı veya yedi ay sonra 1539 yazında Sadrazam Ayas Paşa veba salgınından rahatsızlanıp aniden ölünce (26 Safer 946/13 Temmuz 1539), ikinci vezir Lütfi Paşa sadarete getirilir ve Rüstem Paşa da dördüncü vezir olarak Divan-ı Hümayun üyesi olur. Dolayısıyla Mihrimah Sultan ile

43 Aydın, 89-94.

44 Peirce, The Imperial Harem, 94. "il qual signor ... ha...fatto Chebin, che è come pigliar per legittima moglie ....con farle contradotte di contodiecimila ducati, avendo voluto superar il padre, che alla sultana madre d'esso Selim fece contradote di centomila ducati solamente." Bkz. Jacopo Ragazzoni, "Relazione dell'Impero Ottomano di Jacopo Ragazzoni Presentata del suo Ritorno da Costantinopoli, il 16 Agosto 1571", Relazioni degli Ambasciatori Veneti al Senato, ed. Eugenio Albèri, III, v.2 (Firenze: Società Editrice Fiorentina, 1844), 97.

45 Sakaoğlu, Bu Mülkün Kadın Sultanları, 255-56.

46 Celâlzâde, Țabakāt, 297a-298b. Ayrıca bkz. Mustafa Âlî, Künhü'l-ahbâr, 308a.

47 Celâlzâde, Țabaḳāt, 327a-b. Ayrıca bkz. Mustafa Âlî, Künhüll-ahbâr, 311 b.

48 Danişmend, Kronoloji, c. II, s. 217. 
düğünlerinin olduğu 15-28 Receb/26 Kasım-4 Aralık 1539 tarihlerinden yaklaşık dört-beş ay öncesinde Rüstem Paşa zaten İstanbul'da bir makama getirilmişti. Elbette bu evliliğe karar verilmiş olması Rüstem Paşa'nın terfi süreçlerini hızlandırmış olabilir, fakat İstanbul'a gelişinin düğünden daha önce gerçekleştiği kesindir.

\section{Mihrimah ve Rüstem'in Çocukları}

Kaynaklarda Mihrimah ve Rüstem'in evlilik hayatı hakkında çok az bilgi bulunmaktadır. Bu bilgiler büyük oranda gizliydi veya mahremiyeti korumak amacıyla bilinenler de pek kayda geçmemekteydi. Bu bağlamda çiftin çocuklarının sayısı konusunda da ihtilaf vardır. Genel olarak Ayşe Hümaşah isminde bir kızları olduğu konusunda bütün kaynaklar uzlaşırken Osman isminde bir oğulları olduğu iddiası da söz konusudur. ${ }^{49}$ Bu iddianın temel kaynağı muhtemelen Mehmed Süreyya'nın Sicill-i Osmanî isimli eseridir. Zira burada Rüstem Paşa'nın Osman adında Mihrimah Sultan'dan başka bir kadından doğma oğlu olduğundan bahsedilmektedir. ${ }^{50}$ Belki Rüstem Paşa'nın Mihrimah Sultan ile evlenmeden önce Osman adında bir oğlu vardı ve modern çalışmalar Sicill-i Osmanîddeki bu kayıtta geçen Osman'ı Mihrimah Sultan'ın oğlu olarak aktarmış olabilirler. Fakat ne dönemin çağdaş kaynaklarında ne de vakıf kayıtlarında Rüstem Paşa'nın bu isimde bir oğlu olduğuna dair bir kayıt bulunmamaktadır. Ayrıca bu isimde bir oğulları olsa bile çok erken yaşta ölmüş olmalı, zira 1550'de kayıt altına alınmış olan Mihrimah Sultan'ın Üsküdar'daki cami ve külliye vakfiyesinde kızları Ayşe Sultan ve onun çocukları için günlük harçlık tayin edilmiş fakat burada başka bir çocuğun ismi geçmemiştir. ${ }^{51}$

Bunun yanında Rüstem-Mihrimah çiftinin Ayşe Hümaşah isminde bir kızları olduğunda şüphe yoktur. 25 Ağustos 1547'de doğan bu kız, ${ }^{52}$ daha sonra Semiz Ahmed Paşa ile evlendi. Semiz Ahmed Paşa, Mihrimah Sultan'ın da yardımıyla Sokollu Mehmed Paşa'nın ölümünden sonra 987/1579 yılında sadrazam olmuş, fakat altı ay sonra vefat etmiştir. ${ }^{53}$ Daha sonra Ayşe Hümaşah 990/1582 yılında Nişancı Feridun Bey ile evlenmiş, ancak Feridun Bey 991/1583'te

49 Babinger, "Mihr-i Māh Sulțān," 7; Mustafa Kaçar, "Mihrimah Sultan," 39-40; A.D. Alderson, The Structure of the Ottoman Dynasty Tablo XXX, s. 251; Sakaoğlu, Bu Mülkün Kadın Sultanları, 258. Alderson'un eserindeki tabloya göre Osman'ın doğum tarihi bilinmemektedir. Fakat ölüm tarihi 1576'dır.

50 Mehmed Süreyya, Sicill-i Osmanî, haz. Nuri Akbayar ve Seyit Ali Kahraman (İstanbul: Tarih Vakfı Yurt Yayınları, 1996), 5:1402 ve 4:1286.

51 Necipoğlu, The Age of Sinan, 302; F. Cangüzel Zülfikar, “Mihrimah Sultan'ın Vakıflar Genel Müdürlüğü Arşivinde Bulunan Vakfiyelerinin Değerlendirilmesi" (Yüksek Lisans Tezi, Ankara Üniversitesi, 1989), 57-58.

52 Ayşe Hümaşah'ın doğum tarihini İstanbul'da bulunan Habsburg mukim elçisi Johann Maria Malvezzi'nin I. Ferdinand'a 26 Ağustos 1547 tarihli mektubundan öğreniyoruz. Orada şöyle yazılıdır: “...heri, è nata una figliola ad esso Rustan Bassa..." Krş. Srecko M Dzaja, Karl Nehring, ve Günter Weiß, ed., Austro-Turcica, 1541-1552: diplomatische Akten des habsburgischen Gesandtschaftsverkehrs mit der Hohen Pforte im Zeitalter Süleymans des Prächtigen (München: Oldenbourg, 1995), No: 53, s. 178.

53 Feridun Emecen, “Semiz Ahmed Paşa," TDV İslam Ansiklopedisi, c. 36 (İstanbul, Türkiye Diyanet Vakfı, 2009), 494-495. 
vefat etmiştir. ${ }^{54}$ Ayşe Hümaşah'ın birinci evliliğinden doğan kızı Saliha daha sonra sadrazam da olacak olan Cigalazade Yusuf Sinan Paşa ile evlenecekti. ${ }^{55}$ Böylece Mihrimah Sultan'ın kocası Rüstem Paşa'dan sonra damadı ve kızının damadı da sadrazam olacaktı. Mihrimah Sultan'ın vakfiyesine göre ölümünden sonra vakıflarındaki gelirlerin kontrolü kızı ve torunlarına kalacaktı. ${ }^{56}$

\section{Mihrimah ve Rüstem'in Evlilik Yılları}

Düğünün ardından Mihrimah haremden ayrıldı ve Rüstem Paşa ile birlikte yaşamaya başladı. Yeni çiftin bugünkü İstanbul dahilinde birkaç sarayı vardı. Her ne kadar Mihrimah ve Rüstem'in bu binaların hangisinde hangi tarihten itibaren yaşamaya başladıklarını tam olarak bilemesek de genel olarak hepsini yılı çeşitli zamanlarında kullandıklarını söyleyebiliriz. Mimar Sinan'ın inşa ettiği binalar arasında saydığı üç Rüstem Paşa Sarayı mevcuttur: biri At Meydanı'nda (bugünkü Sultanahmet Külliyesi'nin bulunduğu yerde); biri Üsküdar'da; ve birisi de Bakırköy sınırlarında bulunan İskender Çelebi Çiftliği'nde bulunmaktaydı. ${ }^{57}$ Bunlardan At Meydanı'nda bulunan saray bazı belgelerde "Mihrimah Sultan Sarayı" olarak geçmektedir. ${ }^{58}$ Genellikle yaz aylarında kullanılan Üsküdar'daki sarayın Salacak'ta Kız Kulesi'nin karşısına denk gelen bir bahçe içinde olduğu tarif edilmiştir. ${ }^{59}$ Bunlardan başka bugün Cağaloğlu semtinde bulunan Rüstem Paşa'ya ait bir başka saray daha tespit edilmiş olup, daha sonrasında kızının damadı olacak olan Cigalazade Yusuf Sinan Paşa'nın bu sarayı kullanması sebebiyle bu semte Cağaloğlu ismi verilmiştir. ${ }^{60}$

Rüstem Paşa, Mihrimah ile evliliği sayesinde çok hızlı yükseldi ve 1544 yılında sadrazamlığa getirildi. Sadrazamlığında da sultan tarafından geniş yetkilerle donatıldı. Onun kariyerinde Mihrimah ve doğal olarak Hürrem Sultan önemli bir dayanak noktasıydı. ${ }^{61}$ Dönemin çağdaş gözlemcileri Rüstem'in sahip olduğu gücün Hürrem ve Mihrimah'a dayandığını söylemektedirler. 1550 yılında Venedik balyosu Alvise Renier, sultana her istediklerini yaptırabilen Hürrem ve Mihrimah sayesinde Rüstem'in saygın ve korkulan birisi olduğunu ifade etmekte-

54 Abdülkadir Özcan, "Feridun Ahmed Bey," TDV İslam Ansiklopedisi, c. 12 (İstanbul, Türkiye Diyanet Vakfı, 1995), 396-397.

55 Stephan Gerlach, Türkiye Günlüğü, çev. Türkis Noyan (İstanbul: Kitap Yayınevi, 2006), 1:456-457. Ayrıca bkz. Feridun Emecen, "Semiz Ahmed Paşa."

56 Necipoğlu, The Age of Sinan, 302.

57 Howard Crane ve Esra Akın, (ed.), Sinan's autobiographies: five sixteenth-century texts (Leiden: Brill, 2006), 98.

58 Topkapı Sarayı Müzesi Arşivi, E. 9512. Buradan aktaran Ahmet Arslantürk, "Bir Bürokrat ve Yatırımcı olarak Kanuni Sultan Süleyman'ın Veziriazamı Rüstem Paşa" (Doktora Tezi, Marmara Üniversitesi, 2011), 30-31.

59 Bu sarayın konumu hakkındaki bilgi Rüstem ve Mihrimah'in kızı Ayşe Sultan'ın 1595'te kaydedilmiş vakfiyesinde mevcuttur. Bkz. Vakıflar Genel Müdürlüğü, no. 635/2, 52. Ayrıca bkz. Gülru Necipoğlu, "The Suburban Landscape of Sixteenth-Century in Istanbul as a Mirror of Classical Ottoman Garden Culture," Gardens in the Time of the Great Muslim Empires: Theory and Design içinde, ed. Attilio Petruccioli (Leiden \& New York: Brill, 1997), 40-41.

60 Arslantürk, "Bir Bürokrat ve Yatırımcı olarak Kanuni Sultan Süleyman'ın Veziriazamı Rüstem Paşa”, 30-31.

61 Hürrem ve Mihrimah'ın Rüstem üzerindeki destek ve etkisi hakkında bkz. Zahit Atçıl, "Çağdaşlarının Gözünden Rüstem Paşa'nın Sadrazamlı̆ı (1544-1553 ve 1555-1561)", Halil Inalcık Armağanı-IV içinde, ed. Ahmet Özcan (Ankara: Doğu Batı, 2017), 73-90. 
dir.62 Navagero'nun aktardığına göre, Hürrem ve Mihrimah birlikte Rüstem'in sultan nezdindeki yerini yüceltmek istemiş ve hatta aynı İbrahim Paşa'ya bahşedildiği gibi Rüstem'in de Enderun'a serbestçe girebilme ve sultan ile görüşebilme yetkisi verilmesini talep etmişler, fakat sultan bu isteği “bir kere çılgınlık yapmak yeter" (basta fare una pazzia una volta) diyerek reddetmişti. ${ }^{63} 1557$ yılında Antonio Erizzo ise Rüstem'in sahip olduğu güç ve otoritenin insanların kıskançlık ve nefretini çektiğini ve eğer bu iki kadının desteğini kaybedecek olursa (se gli mancasse il favore delle sultane) kısa sürede eleştirilerin hedef noktası olabileceğini ve hatta konumunu kaybedebileceğini ifade etmektedir. ${ }^{64}$ Rüstem Paşa'nın sultan üzerinde etkili bu iki kadının desteğini almış olması onun uzun süre sadarette kalabilmesine de yardımcı olmuştu. Hatta kısa bir süreliğine (1553-1555 arası) azledilmiş olmasına rağmen, bu hanımların desteği ile yeniden sadarete gelebilmişti. 1555 yılında Sadrazam Kara Ahmed Paşa'nın aniden idam edilmesi ile Rüstem'in yeniden sadarete atanmasını değerlendirirken tarihçi Mustafa Âlî, Ahmed Paşa'nın “bilâ günâh” öldürüldüğünü, Rüstem'in ise “mekr-i zenân” ile yeniden sadarete geldiğini söyleyerek Hürrem ve Mihrimah'ın etkisine işaret etmektedir.65 Kısaca, Rüstem, Mihrimah ile evlenmesinden sonra hem karısının hem de kayınvalidesi Hürrem Sultan'ın desteği ile büyük bir güç ve otoriteye kavuşmuştu. Dolayısıyla bu evlilik, 16. yüzyıldaki Osmanlı hanedanının evlilik politikaları çerçevesinde, devşirme usulü ile gelen ve yetiştirilen bir kişinin kariyerini daha da yükseltme işlevi görmekteydi.

Bu desteğin karşılığı olarak da yaklaşmakta olan veraset mücadelelerinde Rüstem, Mihrimah ile birlikte Hürrem'in yanında yer almakta ve o zamanlar oldukça revaçta olan Şehzade Mustafa'ya karşı tahtın Hürrem'in çocuklarından birisine geçmesi için çabalamaktaydı. Elbette Hürrem'in çocuklarından birisinin Süleyman'dan sonra padişah olması Rüstem'in de menfaatineydi. 1550'lerin başlarında iyice kızışan bu rekabet artık sultanın da kontrolünden çıktı. Nihayet 27 Şevval 960/6 Ekim 1553 günü Nahçıvan Seferi esnasında Şehzade Mustafa sultanın emri ile boğduruldu ve böylece tahtın artık Hürrem'in oğullarından iki muhtemel adaydan

62 "....et in vero questa diletta moglie con la figliola, che è moglie del magnifico Rusten è fama che fano fare quanto voleno al Signor, de donde depende la summa auttorità et stabilimento presso il Signor del magnifico Rusten temuto et reverito da ogn'uno." Alvise Renier, "Relazione", Relazioni di Ambasciatori Veneti al Senato: Costantinopoli, Relazioni Inedite (1512-1789), ed. Maria Pia Pedani-Fabris (Padova: Bottega D'Erasmo - Aldo Ausilio Editore, 1996), 75.

63 Navagero, "Relazione", 90. Aynı konuda Hürrem ve Mihrimah'ın Rüstem için taleplerinin sultan tarafından reddedilmesi hakkında bkz. Domenico Trevisano, "Relazione dell'Impero Ottomano del Clarissimo Domenico Trevisano, Tornato Bailo da Costantinopoli sulla fine del 1554", Relazioni degli Ambasciatori Veneti al Senato, ed. Eugenio Albèri, III, v.1 (Firenze: Tipografia e Calcografia all'Insegna di Clio, 1840), 120.

64 Antonio Erizzo, "Sommario della Relazione di Antonio Erizzo, Bailo a Costantinopoli letta in Senato nel 1557", Relazioni degli Ambasciatori Veneti al Senato, ed. Eugenio Albèri, III, v.3 (Firenze: Società Editrice Fiorentina, 1855), 136.

65 Mustafa Âlî, Künhü'l-ahbâr, 360a-b. Ayrıca Ahmed Paşa'nın idamı ve Rüstem Paşa'nın sadarete getirilmesinde Hürrem ve Mihrimah'ın rol oynadığı fikrinin başka bir ifadesi için bkz. Marcantonio Donini, “Relazione dell'Impero Ottomano di Marcantonio Donini Segretario del Bailo Girolamo Ferro Letta in Pregadi l'Anno 1562", Relazioni degli Ambasciatori Veneti al Senato, ed. Eugenio Albèri, III, v.3 (Firenze: Società Editrice Fiorentina, 1855), 184.; Stephan Gerlach, Türkiye Günlüğü, 2:729. 
birine yani Selim ya da Bayezid'e kalması kesinleşti. ${ }^{66}$ Fakat bu sefer esnasında gerçekleşen bu olay vesilesi ile ordunun moralinin düşmesi ve sultana karşı eleştirilerin yükselmesi sonucu Rüstem Paşa azledildi. ${ }^{67}$

Ardından İstanbul'a dönen Rüstem, sultan seferden dönene kadarki süreyi Üsküdar'daki sarayda geçirdi. Her ne kadar Rüstem'in artık resmi bir görevi olmasa da İstanbul'da kendisine saygı gösterilmeye devam edildi. Mesela, o esnada İstanbul'a ulaşan Habsburg elçisi Ogier Ghiselin de Busbecq beraberinde getirdiği diğer elçilik görevlileri ile Rüstem Paşa'yı Üsküdar'daki sarayda ziyaret etti. ${ }^{68} 0$ esnada Venedik balyosu olan Domenico Trevisano'nun aktardığına göre, her ne kadar Rüstem Paşa'nın pek sevilmediği bilinse de o hala önemli biri olarak düşünmekteydi. Trevisano bu gerçekten hareketle Rüstem'in vazifesiz döneminin geçici olduğunu tahmin etmekte kendisinden sonra gelecek balyosun da Rüstem Paşa'ya her halükârda saygı göstermesi gerektiğini tavsiye etmekteydi. ${ }^{69}$ Nitekim Venedik senatosu ve yeni gelen elçi Antonio Erizzo bu tavsiyeyi ciddiye almış ve mazûl sadrazamı Üsküdar'daki sarayında ziyarete devam etmişti. ${ }^{70}$ Kısacası, Rüstem mazûl olsa bile, Mihrimah ile birlikte yaşadıkları Üsküdar Sarayı eskisi gibi her gün ziyaretçilerle dolmuştu.

Bu ziyaretçi yoğunluğunun muhtemelen üç sebebi vardı. Birincisi, azledilmiş olmasına rağmen Mihrimah ile evli kalması, Rüstem'in sultanın gözünde hala önemli bir yere sahip olduğuna işaret etmekteydi. Yine Süleyman döneminde hanedanın bir üyesi, Süleyman'ın kız kardeşi Şah Sultan ile evli olan Lütfi Paşa 1541 'de azledilince boşandırılmış ve hanedanla olan evlilik bağı son bulmuştu. Fakat Rüstem Paşa'nın azlinden sonra herhangi bir boşanma gerçekleşmemiş olması Rüstem'in hala saygıdeğer bir konumda olduğunu düşündürmekteydi. Nitekim hem Mihrimah'ın hem de Hürrem'in desteği ile Rüstem 1555 yılında yeniden sadarete gelebilmişti. Rüstem'in mazûl olduğu dönemde Hürrem'in Süleyman'a yazdığı bir mektupta bu desteğin izleri açıkça görülmektedir. Hürrem burada sultandan Rüstem'e teveccühünü esirgememesini ve Şehzade Mustafa'nın boğdurulması ile bağlantılı olarak paşanın itibarının bozulmasına müsaade etmemesini rica etmektedir ve bunu sultandan Mihrimah'ın ve kendisinin hatırı için talep etmektedir:

66 Şehzade Mustafa'nın boğdurulmasının arka planı ve sürecin aşamaları için bkz. Zahit Atçı, "Why Did Süleyman the Magnificent Execute His Son Şehzade Mustafa in 1553?," Osmanlı Araştırmaları 48 (2016), 67-103.

67 Atçıl, "The Grand Vizierates of Rustem Pasha (1544-1561)," 116-23.

68 Ogier Ghislain de Busbecq, The Turkish Letters of Ogier Ghiselin De Busbecq, Imperial Ambassador at Constantinople, 1554-1562, çev. Edward Seymour Forster (Baton Rouge: Louisiana State University Press, 2005), 28.

69 Trevisano, “Relazione”, 175-76. Trevisano'nun yeni gelecek olan balyosa Rüstem Paşa'ya saygı göstermesi hususundaki tavsiyesi için bkz. Archivio di Stato di Venezia, Senato, Dispacci Costantinopoli, Filza 1-A, n. 8, fol. $14 \mathrm{r}$ ve ayrıca bkz. Archivio di Stato di Venezia, Senato, Deciferazioni dei Dispacci da Costantinopoli, Reg. 1, fol. 7.

70 Rüstem Paşa'ya takdim için verilen tavsiye mektubunu Erizzo'nun paşaya teslim etmesi hakkında bkz. Archivio di Stato di Venezia, Senato, Dispacci Costantinopoli, Filza 1-A, n. 15, fol. 49r. 
[...] benim devletlüm iki gözüm yoluna kurban olduğum saadetüm bendenüz Rüstem Paşa bendenüzdür, nazar-ı şerifiniz üzerinden diriğ itmiyesiz, benim devletüm kimsenin sözüne amel etmiyesiz, hele şol cariyen Mihrimah'ın yüzü suyuna benüm devletüm benüm padişahım aziz başınız için ben cariyen dahi hatırı için olsun saadetlü Padişahım. ${ }^{11}$

İkincisi, Rüstem azledilip İstanbul'a döndüğünde padişah ordu ile birlikte Nahçıvan Seferi'ndeydi ve İstanbul'un muhafazası için de (muhtemelen Rüstem'in aktif rolü ile) Rüstem'in kardeşi Kaptan-I Derya Sinan Paşa tayin edilmişti. Bu süre içinde padişah adına başkentte tam yetkili kişi Sinan Paşa'ydı. Aslında dönemin bazı çağdaş kaynakları Sinan Paşa'nın kaptanlık makamını hak etmediğini ve onun bu göreve ağabeyi Rüstem Paşa sayesinde geldiğini ifade etmektedir.72 Dolayısıyla, her ne kadar Sinan Paşa o esnada İstanbul'da tam yetkili kişi olsa da asıl karar vermeye salahiyetli kişinin Rüstem Paşa olduğu herkesçe bilinmekteydi. Başka bir deyişle, Rüstem mazûl olsa bile sadrazam gibi yönetmeye devam ediyordu, o yüzden de Üsküdar'daki sarayında ziyaretçiler eksik olmuyordu.

Üçüncü muhtemel bir sebep ise Şehzade Mustafa'nın boğdurulması hadisesinin hemen ardından Süleyman'a karşı yükselen öfke ve eleştirileri dindirmek için Rüstem'in anlaşmalı olarak azledilmiş olduğu ve işler yoluna girince sultanın onu yeniden makamına getirmeye söz vermiş olabileceğidir. ${ }^{73}$ Nitekim Busbecq, bu olumsuz atmosferde Rüstem'in hem kendi canını kurtarmak hem de sultanın bozulan imajını düzeltmek için kendi azlini istediği dedikodularından bahsetmektedir. ${ }^{74}$ Dolayısıyla, Rüstem Paşa ordudan ayrılıp İstanbul'a geldiğinde, sultan ile kendileri arasında muhtemel bir anlaşmaya binaen kendisinin yeniden sadarete geleceğini yaymış olabilir. Nitekim sultan İstanbul'a döndükten sonra Rüstem'in yeniden sadarete

71 M. Çağatay Uluçay, Osmanlı Sultanlarına Aşk Mektupları (İstanbul: Șaka Matbaası, 1950), 43.

72 Mesela Navagero açık bir şekilde Sinan Paşa'nın deniz işlerinde pek tecrübesi olmadığını ifade etmektedir. Bunun yanında diğer kaptanların bu tecrübesiz kaptan-ı deryaya saygı göstermelerinin ve itaat etmelerinin tek sebebini ağabeyinin sadrazam olmasına bağlamaktadır. (Il capitano di mare, che ora si trova avere il Gran-Signore è poco pratico delle cose del mare, perchè non ha avuto mai nè carico, nè pratica alcuna di questa milizia: è però obbedito e stimato più che ogni alctro capitano che fosse essendo fratello di chi è....). Bkz. Navagero, "Relazione”, 70. Tarihçi Mustafa Âlî ve Katip Çelebi de Sinan Paşa'nın tecrübesizliğine işaret etmekte fakat o zamanlarda denizcilikte daha tecrübeli olan Turgut Reis'in kaptanlığa getirilmemesini Rüstem Paşa'nın tercihine bağlamaktadır. Bkz. Mustafa Âlî, Künhü'l-ahbâr, 329a-31; Kâtip Çelebi, Tuhfetü'l-Kibâr fî Esfâri'l Bihâr : Deniz Seferleri Hakkında Büyüklere Armağan, ed. İdris Bostan (Ankara: Başbakanlık Denizcilik Müsteşarlığı, 2008), 100-106.

73 Çok sevilen Şehzade Mustafa'nın boğdurulması orduda morali bütünüyle bozmuştu. Süleyman'ı da hedef alan birçok söz söylenmişti. Bunların en meşhur olanı ise şair Yahya Bey'in Şehzade Mustafa mersiyesidir. Yahya Bey ve mersiyesi için bkz. Mustafa Âlî, Künhü'l-Ahbâr, 325a-326a; Mustafa Âlî, Künhü'l-Ahbâr'ın Tezkire Kısmı, ed. Mustafa İsen (Ankara: Atatürk Kültür Merkezi, 1994), 286; Âşık Çelebi, Meşā'irü'ş-Şu'arā, ed. G. M. MeredithOwens (London: Luzac, 1971), 95b; A. Atillâ Şentürk, Yahyâ Beğ'in Sehzâde Mustafa Mersiyesi Yahut Kanuni Hicviyesi (İstanbul: Enderun Kitabevi, 1998). Sefer esnasında ordu ile birlikte olayları gözlemleyen bir Venedikli, orduda sultana karşı büyük bir öfke duyulduğunu ve eleştirilerin kamp yerinde sultanın da duyabileceği şekilde yüksek sesle dile getirildiğini aktarmaktadır. Bkz. “Relazione Anonima della Guerra di Persia dell'anno 1553 e di Molti Altri Particolari”, Relazioni degli Ambasciatori Veneti al Senato, III, v.1 (Firenze: Tipografia e Calcografia all'Insegna di Clio, 1840), 212-13.

74 Busbecq, The Turkish Letters, 33. 
getirilmesinin biraz gecikmesi o dönemin gözlemcilerini şaşırtmıştı. ${ }^{75}$ Fakat çok geçmeden 13 Zilka'de 962/29 Eylül 1555 günü Ahmed Paşa idam edildi ve Rüstem yeniden sadarete getirildi. ${ }^{76}$ Dolayısıyla, Mihrimah ve Rüstem'in ikamet ettikleri Üsküdar Sarayı paşanın mazûl olduğu dönemlerde de sürekli meşguldü.

Mihrimah'ın desteği ve önceki gücünün etkisi ile halen saygınlığını koruyan Rüstem Paşa'nın mazûl olduğu İstanbul günlerinde bütün varlığını kaybetme riskini taşıdığı en büyük hadise karısının geçirdiği bir hastalığa uzun bir süre çare bulunamamasıydı. Rüstem'in İstanbul'a dönmesinden kısa bir süre sonra Mihrimah ciddi bir hastalığa yakalandı ve doktorların teşhis ve tedavileri hiçbir şekilde işe yaramadı. Giderek umutların yitirildiği bir sırada Mihrimah Sultan'ı iyileştirmeyi Pedro ismiyle bilinen Sinan Paşa'nın bir İspanyol esiri başarabilmişti. Pedro, Andrea Doria'nın kaptanlığında Akdeniz'de Cenova'dan Napoli'ye giderken Sinan Paşa'nın kaptanlığındaki Osmanlı donanmasının saldırısına uğrayıp ele geçirilen esirlerden biriydi. İstanbul'a gelirken birçok fiziksel işten kurtulabilmek için kendisini hekim olarak tanıtmıştı ve çeşitli basit hastalıklara o zamana kadar okuduğu birkaç tıp kitabındaki tariflerden bazı ilaçlar hazırladı ve bunlar da şans eseri veya gerçekten etkili ilaç oldukları için işe yaradı. Sonrasında kendi anlatımına göre Yahudi hekimlerin çare bulamadığı Sinan Paşa'nın astımını bazı şuruplarla hafifletti ve böylece ünü arttı. Tam o sıralarda Mihrimah'ın hastalığına çare bulunamaması sebebiyle umutsuzluğa kapılan Rüstem'e kardeşi Sinan bu İspanyol hekimi tavsiye eder. Sinan Paşa, hekimi yanına çağırıp hastanın bir hanım sultan olduğunu ve hem kendisinin hem de ağabeyinin kaderinin bu kadına bağlı olduğunu ifade eder. Hastayı iyileştirmesi karşılığında esire özgürlüğünü vadeden Sinan Paşa, eğer hasta ölürse kendisinin ve ağabeyinin mahvolacağını söyler. ${ }^{77}$ Pedro'nun hastayı görmek istemesine Sinan Paşa başta itiraz eder, fakat sonrasında Rüstem'in rızası ile kabul eder. İspanyol esir, Üsküdar'daki saraya Mihrimah Sultan'ı muayene etmeye gider. Mihrimah üstü bir çarşafla örtülü halde yatakta yatmaktaydı. İspanyol esir ilk önce Mihrimah'ın bir elinden nabzını ölçer, sonra diğer elinden ölçmek daha sonra da diline bakmak ister. Rüstem Paşa esirin fazla ileri gittiğini düşünerek tedirgin olsa da Mihrimah muayene etmesine izin verir. Sonrasında esir bir tatlı şurup verir. Her ne kadar bu olayı duyan hekimler, Rüstem Paşa'ya İspanyol esirin sahtekâr olduğunu ve ona güvenmemesi gerektiğini söyleseler de sonunda, esirin kendi anlatımına göre, Mihrimah onun tedavi yöntemi ile iyileşir. ${ }^{78}$ Böylece hem Rüstem Paşa'nın hem de Sinan Paşa'nın kariyerlerinin sigortası olan kadın iyileşmiş olur.

Mihrimah Sultan'ın hayatı sadece Rüstem için değil aynı zamanda Kaptan-ı Derya Sinan Paşa için de çok önemliydi. 0 sıralar zaten hasta olan Sinan Paşa kısa bir süre sonra vefat etti.

75 Rüstem Paşa'nın yeniden tayin olunmasının neden geciktiğini açıktan paşaya soran Antonio Erizzo'nun mektubu için bkz. Archivio di Stato di Venezia, Senato, Dispacci Costantinopoli, Filza 1-A, n. 50, fol. 125R-126V ve ayrıca Archivio di Stato di Venezia, Senato, Deciferazioni dei Dispacci da Costantinopoli, Reg. 1, fol. 138-141.

76 BOA, A.RSK 1455, s. 7. Celâlzâde, Ṭabaḳāt, 501b; Mustafa Âlî, Künhü'l-Ahbâr, 337a.

77 "que la enferma era una señora de quien él y su hermano y todos ellos dependían; de tal arte, que si ella moría todos quedaban perdidos," Bkz. Cristóbal de Villalón, Viaje de Turquia (Madrid: Espasa-Calpe, S. A., 1919), 1:139-140. Türkçesi için bkz. Türkiye Seyahati, çev. Yeliz Demirhan (İstanbul: Erko Yayıncılık, t.y.), 99-100.

78 Cristóbal de Villalón, Viaje de Turquia 1:140-151. Türkçesi için bkz. Türkiye Seyahati, 100-106. 
Yine İspanyol esirin aktardığına göre, Sinan Paşa vefatında bütün servetini kendi çocukları yerine Mihrimah'a vasiyet etti. ${ }^{79}$ Belki çocuklarının o zamanlar servetini idare etmek için henüz küçük olduklarını düşündüğü için Sinan böyle vasiyet etmişti. Aslında Mihrimah'ın ve eğer eski konumuna gelirse ağabeyi Rüstem'in yeğenlerini kollayacağını biliyordu. Nitekim, Sinan Paşa'nın İbrahim ve Osman adında iki oğlu Budin Beylerbeyliği içinden zeamet elde edeceklerdi. ${ }^{80}$

Mihrimah'ın etrafındaki insanlar için önemi tartışılmaz bir gerçekti. Rüstem de yeniden göreve gelmesinden sonra yine önceden olduğu gibi onunla birlikte Hürrem'in başını çektiği hizbin aktif üyesi olmaya devam ettiler. Artık Osmanlı tahtı Süleyman'dan sonra Hürrem'in çocuklarından birine geçecekti fakat bu sefer geriye kalan iki aday, Selim ve Bayezid, birbirine düştü. Sultan şehzadelerin sancaklarını değiştirmeye karar verdi, Bayezid bu değişikliğe direndi, çünkü tahta oturabilmek için pasif bir şekilde beklemek yerine aktif olarak öne çıkmayı tercih etti. Hürrem Sultan bu aşamada büyük bir ikilemde iken 1558 yılında vefat edince iş daha da kızıştı. Başta tarihçi Mustafa Âlî olmak üzere, çağdaş gözlemcilerin bazıları Hürrem ve onunla birlikte olan Mihrimah-Rüstem ikilisinin Bayezid'e yakın olduğunu iddia etmekteydi. ${ }^{81}$ Fakat bazıları ise bu hizbin aslında Selim'i desteklediğini belirtmektedir. ${ }^{82}$ Venedik balyosu Girolamo Ferro'nun sekreteri Marcantonio Donini, Mihrimah'ın Osmanlı veraset meselesinde çok aktif bir rol oynadığını, ilk önce Şehzade Mustafa'nın öldürülmesinde etkili olduğunu, şimdi de mücadeleyi Bayezid'in kazanması için ona birçok defa ve birçok vesile ile büyük miktarda para gönderdiğini ifade etmektedir. Ayrıca Bayezid'e yardım etmesinin de müteveffa annesi Hürrem'in vasiyeti olduğu söylentisinin dolaştığını aktarmaktadır. ${ }^{83}$ Mihrimah, Sultan Süleyman'ın ikazı ile iki şehzade arasındaki mücadelede açıktan taraf tutmamış gözükmektedir. Hatta Bayezid'in çeşitli seferlerde yardım talep eden mektuplarına da nasihat ederek cevap vermiştir. ${ }^{84}$ Sonunda, Bayezid ve Selim Konya'da savaşırlar ve iyice gözden düşmüş olan Bayezid yenilince İran'a Safevilere sığınır. Hem Süleyman hem de artık tahtı garanti altına almış olan Selim'in elçilerinin yaptığı müzakereler ile Safeviler, Bayezid'i teslim ederler ve şehzade hemen boğdurulur (1562). 0 vakit Bayezid'in en büyük destekçisi durumunda bulunan Mihrimah'ın çok kederlendiği ve hatta Bayezid'in ölümünden bir yıl önce vefat eden kocası Rüstem'in ölümünden daha fazla üzüldüğü rivayet edilmektedir. ${ }^{85}$

Evliliklerinin son dönemi Bayezid-Selim mücadelesi ile geçen çiftin özel hayatına dair

79 Villalón, 206.

80 BOA, Tapu Tahrir Defterleri, no: 329, s. 20. (Bu defter ve bu bilgiden beni haberdar eden Arif Bilgin'e teşekkür ederim.)

81 Mustafa Âlî, Künhü'l-ahbâr, 340b-349b.

82 Dzaja, Nehring, ve Weiß, Austro-Turcica, 243-50 ve 398. Bu hizbin duruşu ve genel olarak Bayezid-Selim mücadelesi için bkz. Şerafettin Turan, Kanunî'nin Oğlu Şehzâde Bayezid Vak'ası (Ankara: Türk Tarih Kurumu, 1961).

83 Donini, “Relazione”, 184.

84 Turan, Kanunî́nin Oğlu Şehzâde Bayezid Vak'ası, 83-103.

85 Archivio di Stato di Venezia, Senato, Dispacci Costantinopoli, Filza 3-C, n. 79, fol. 235r. “...ha mostrato di haver sentito per questa morte assai dolore, che non senti per quella di Rustem bassa suo marito.." 
bilgiler pek sınırlıdır. Bu sürede hem Mihrimah hem de Rüstem kendi adlarına başkentte ve Osmanlı coğrafyasının birçok yerinde camiler, medreseler, imaretler, kervansaraylar ve birçok hayır kurumu vakfettiler. ${ }^{86}$ Rüstem yakalandığı “istiska” hastalığına pek dayanamadı ve 9 Temmuz 1561 'de vücudunda biriken fazla su sebebiyle vefat etti. Rüstem'in vefatıla birlikte serveti de Mihrimah'a kaldı. Kayıtlı vakfiyelerine göre Rüstem vakıflarının tevliyeti kızı Ayşe Sultan'a kalacaktı ve bu konuda vekili Mehmed Kethüda yardımcı olacaktı. ${ }^{87}$

Bu tarihten itibaren Mihrimah ölümüne kadar dul bir kadın olarak yaşamıştır. Başlarda Mihrimah müteveffa kocasının sadareti döneminde sahip olduğu siyasi etkinin kocasının ölümünden sonra azalmasından korkmuştu. Nitekim, Venedik balyosu Daniele Barbarigo'nun raporuna göre, Rüstem Paşa'nın vefatından sonra sadrazam olan Semiz Ali Paşa'ya kendisiyle evlenmesini teklif etmişti ama paşa evlenmeyi düşünmediğini söyleyerek bu teklifi geri çevirmişti. ${ }^{88}$ Fakat Mihrimah hanedanın dul bir kadın üyesi olarak siyaseten etkili olmaya devam etti. Nitekim hem kızı Ayşe Sultan'ın evlendiği Semiz Ahmed Paşa hem de onların kızları kendisinin torunu Saliha ile evlenen Cigalazade Yusuf Sinan Paşa'nın kariyerlerinin yükselmesinde önemli roller oynamıştı. Hem kontrol ettiği siyasi ağı hem de serveti ile halen çok önemli bir kadındı. Mesela, 1565'te kendi hesabından kadırgalar hazırlayarak Süleyman'ı Malta Seferi'ne teşvik etmişti. ${ }^{89}$ II. Selim 1566'ta tahta çıkınca, cülus bahşişi gibi bazı masraflar için Mihrimah yeni sultana 50000 altın sultani borç vermişti. ${ }^{90}$ Kızını da o zamanlar yeniçeri ağası olup gelecek vadeden Ahmed Ağa ile evlendirmişti. Bir vakit Ahmed Ağa vezirlikten tekaüde ayrıldığında, Selânikî’nin ifadesi ile “Mihrimah Sultan hazretleri şefâ'at eyleyüp, yine vezaret mukarrer [buyuruldu]..."91 Nitekim Sokollu Mehmed Paşa'nın vefatından sonra Semiz Ahmed Paşa sadrazam olmuştu. Mihrimah 25 Ocak 1578'de vefat etmiş ve mirasını kızı Ayşe Sultan'a bırakmıştır. Gerlach'ın aktardığına göre, Mihrimah'ın günlük 2000 düka geliri olup, her hafta kızı ve damadına 2000 düka göndermekteydi. ${ }^{92}$ Kısacası, dul bir kadın olarak Mihrimah, Rüstem'in ölümünden sonra daha sınırlı da olsa zaman zaman siyaseten etkili olmaya devam etmiştir.

86 Mihrimah Sultan vakıflarının listesi ve değerlendirmesi için bkz. F. Cangüzel Zülfikar, “Mihrimah Sultan'ın Vakıflar Genel Müdürlüğü Arşivinde Bulunan Vakfiyelerinin Değerlendirilmesi" (Yüksek Lisans Tezi, Ankara Üniversitesi, 1989); Rüstem Paşa vakıfları için bkz. İ. Aydın Yüksel, “Sadrâzam Rüstem Paşa'nın Vakıfları”, Ekrem Hakkı Ayverdi Hatıra Kitabı (İstanbul: İstanbul Fetih Cemiyeti, 1995), 219-81; İ. Aydın Yüksel, “Rüstem Paşa'nın Vakıfları ve İstanbul'daki Vakıf Eserleri," Vakıf Medeniyeti Sempozyumu Kitabı, 12-13 Mayıs 2003 içinde (Ankara: Vakıflar Genel Müdürlüğü, 2003), 223-59; Necipoğlu, The Age of Sinan, 578; Arslantürk, "Bir Bürokrat ve Yatırımcı olarak Kanuni Sultan Süleyman'ın Veziriazamı Rüstem Paşa."

87 Necipoğlu, The Age of Sinan, 317.

88 Archivio di Stato di Venezia, Senato, Dispacci Costantinopoli, Filza 3-C, n. 73, fol. 220 r-v.

89 Necipoğlu, The Age of Sinan, 297; Peirce, The Imperial Harem, 65.

90 Selânikî Mustafa Efendi, Tarih-i Selânikî (Ankara: Türk Tarih Kurumu, 1999), 1:43.

91 Selânikî, Tarih-i Selânikî, 1:185-186.

92 Gerlach, Türkiye Günlüğü, 2:723. 


\section{Sonuç}

Osmanlı hanedanının evlilik politikalarına genel olarak baktığımızda evlilik tercihlerinin yeknesak olmadığını görürüz. Başlangıçta bir uç beyliği olarak hayatta kalmaya çalışan Osmanlılar kendi aile mensuplarının evliliklerini diplomatik ilişkinin bir parçası olarak görmekteydiler. Zamanla prestijleri arttıkça evliliğe bakışları da değişmeye başladı. 15. yüzyılda hanedan kendisini devam ettirmek için hukuki evlilik yapmak yerine cariyelere yönelmeye başladı. Ayrıca hanedanın kızlarını da aristokrat kökenli Osmanlı eliti ile iş birliği yapmak amacıyla evlendirme eğilimi arttı. 16. yüzyıla gelindiğinde ise evlilik politikası temelde hanedan kızlarını kariyeri yükselecek vezir adayları ile evlendirme şekline büründü. Sultanlar genellikle cariyeler ile birlikte olurken bazen bu cariyeler (Hürrem ve Nurbanu örneğinde olduğu gibi) azat edilip bunlarla resmi nikah yolu ile evlenildiği de görülmektedir.

Süleyman'ın tek kızı olan Mihrimah da kabiliyetleri ve sadakati ile gelecek vadeden devşirme kökenli bir vezir adayı olan Rüstem Paşa ile evlendi. Bu evlilikle hem Rüstem Paşa kariyerinde hızlı ilerledi hem de sultan yetkilerini kendisine devredeceği sadık bir bürokrata sahip oldu. Evlilik yıllarındaki olaylar zincirine bakarsak, Rüstem Mihrimah ile birlikte kayınvalidesi Hürrem Sultan ile aynı tarafta olup saltanat mücadelesi içinde de aktif olarak yer aldı. Bunun karşılığı olarak hem Hürrem'in hem de Mihrimah'ın büyük desteğini gördü. Zira çağdaş gözlemcilerin de belirttiği gibi, kariyeri ve gücü bir anlamda Mihrimah ile evli olmasına bağlıydı. Nitekim, Mihrimah ile evli olmasa Rüstem kariyerinde bu kadar hızlı ilerleyebilir miydi? Veya bu kadar uzun süre sadarette kalabilir miydi? Ayrıca, 1553 yılında azledildikten sonra tekrar sadrazam olması da Mihrimah ile evli olmasıyla yakından bağlantılıydı. Dolayısıyla, 16. yüzyıl itibariyle Osmanlı hanedanı kendi gücünü ve meşruiyetini tahkim ettikçe evlilik politikalarını buna uygun olarak adapte etmişti. Artık evlilikler başlarda olduğu gibi bir ittifak veya diplomatik araç olmaktan ziyade hanedana siyasi olarak hizmet etme görevi görüp hanedanın bazı vezir adaylarını onurlandırma aracı olarak kullanılmaktaydı. Mihrimah ile Rüstem Paşa'nın evliliği de hanedanın gücünün seviyesini göstermeye ve bu evliliğin hanedan üyeleri için nasıl kullanıldığına bir örnek teşkil etmektedir.

\footnotetext{
Hakem Değerlendirmesi: Dış bağımsız.

Çıkar Çatışması: Yazar çıkar çatışması bildirmemiştir.

Finansal Destek: Yazar bu çalışma için finansal destek almadığını beyan etmiştir.
}

Peer-review: Externally peer-reviewed.

Conflict of Interest: The author has no conflict of interest to declare.

Grant Support: The author declared that this study has received no financial support. 


\section{Bibliyografya/Bibliography}

Afyoncu, Erhan. "Rüstem Paşa." TDV İslam Ansiklopedisi. 35:288-290. İstanbul: Türkiye Diyanet Vakfı, 2008. Alderson, A. D. The Structure of the Ottoman Dynasty. Westport: Greenwood Press, 1956.

Altundağ, Şinasi ve Turan, Şerafettin. “Rüstem Paşa." İslam Ansiklopedisi. 9:800-802. İstanbul: Milli Eğitim Bakanlığı, 1993.

Anonim. "Relazione Anonima della Guerra di Persia dell'anno 1553 e di Molti Altri Particolari." Relazioni degli Ambasciatori Veneti al Senato, III, v.1. ed. Eugenio Albèri. Firenze: Tipografia e Calcografia all'Insegna di Clio, 1840.

Arslantürk, Ahmet. “Bir Bürokrat ve Yatırımcı olarak Kanuni Sultan Süleyman'ın Veziriazamı Rüstem Paşa." Doktora Tezi, Marmara Üniversitesi, 2011.

Âşık Çelebi. Meşāirü’ş-Şu'arā. ed. G. M. Meredith-Owens. London: Luzac, 1971.

Âşıkpaşazade. Osmanoğulları'nın Tarihi: Tevârîh-i Âl-i Osmân. neşr. Kemal Yavuz ve M. A. Yekta Saraç. İstanbul: Gökkubbe, 2007.

Atçıl, Zahit. "Çağdaşlarının Gözünden Rüstem Paşa'nın Sadrazamlığı (1544-1553 ve 1555-1561).", Halil Inalcık Armağanı-IV içinde 73-90, ed. Ahmet Özcan. Ankara: Doğu Batı, 2017.

Atçıl, Zahit. "State and Government in the Sixteenth Century Ottoman Empire: The Grand Vizierates of Rustem Pasha (1544-1561)." Doktora Tezi, The University of Chicago, 2015.

Atçıl, Zahit. "Why Did Süleyman the Magnificent Execute His Son Şehzade Mustafa in 1553?." Osmanlı Araştırmaları 48 (2016): 67-103.

Aydın, M. Akif. "Osmanlı Hukukunda Nikâh Akitleri." Osmanlı Araştırmaları 3 (1982): 1-12.

Aydın, M. Akif. Osmanlı Aile Hukuku. İstanbul: Klasik, 2017.

Babinger, Franz. “Mihr-i Māh Sulțān.” Encyclopaedia of Islam, Second Edition. 7:7. Leiden: Brill, 1993.

Busbecq, Ogier Ghislain de. The Turkish Letters of Ogier Ghiselin De Busbecq, Imperial Ambassador at Constantinople, 1554-1562, çev. Edward Seymour Forster. Baton Rouge: Louisiana State University Press, 2005.

Cavalli, Marino. "Relazione dell'Impero Ottomano di Marino Cavalli, stato bailo a Costantinopoli nel 1560." Eugenio Albèri (ed.), Relazioni degli Ambasciatori Veneti al Senato. ser. III. c.1 Firenze: Tipografia e Calcografia all'Insegna di Clio, 1840.

Crane, Howard ve Akın, Esra (ed.). Sinan's Autobiographies: Five Sixteenth-Century Texts. Leiden: Brill, 2006.

Danişmend, İsmail Hami. İzahlı Osmanlı Tarihi Kronolojisi. İstanbul: Türkiye Yayınevi, 1947. 5 cilt.

Donini, Marcantonio. “Relazione dell'Impero Ottomano di Marcantonio Donini Segretario del Bailo Girolamo Ferro Letta in Pregadi l'Anno 1562." Relazioni degli Ambasciatori Veneti al Senato, III, v. 3. ed. Eugenio Albèri. Firenze: Società Editrice Fiorentina, 1855.

Dukas. İstanbul'un Fethi: Dukas Kroniği 1341-1462. çev. V. Mirmioğlu İstanbul: Kabalcı, 2013.

Dzaja, Srecko M, Karl Nehring ve Weiß, Günter (ed.). Austro-Turcica, 1541-1552: diplomatische Akten des habsburgischen Gesandtschaftsverkehrs mit der Hohen Pforte im Zeitalter Süleymans des Prächtigen. München: Oldenbourg, 1995.

Emecen, Feridun. "Semiz Ahmed Paşa." TDV İslam Ansiklopedisi. 36:494-495. İstanbul: Türkiye Diyanet Vakfı, 2009.

Erizzo, Antonio. "Sommario della Relazione di Antonio Erizzo, Bailo a Costantinopoli letta in Senato nel 1557." Relazioni degli Ambasciatori Veneti al Senato, III, v.3. ed. Eugenio Albèri. Firenze: Società Editrice Fiorentina, 1855. 
Fisher, Alan. "Süleymân and His Sons." Gilles Veinstein (ed.) Soliman le Magnifique et son Temps: Actes du Colloque De Paris, Galeries Nationales Du Grand Palais, 7-10 Mars 1990 içinde 117-124. Paris: Documentation française, 1992.

Gerlach, Stephan. Türkiye Günlüğü. çev. Türkis Noyan. İstanbul: Kitap Yayınevi, 2006. 2 cilt.

Isom-Verhaaren, Christine. “Mihrimah Sultan: A Princess Constructs Ottoman Dynastic Identity." Living in the Ottoman Realm: Empire and Identity, 13th to 20th Centuries içinde 150-166. ed. Christine IsomVerhaaren ve Kent F. Schull. Bloomington: Indiana University Press, 2016.

Isom-Verhaaren, Christine. "Süleyman and Mihrimah: The Favorite's Daughter." Journal of Persianate Studies 4:1 (2011): 64-85.

Kaçar, Mustafa. "Mihrimah Sultan." TDV İslam Ansiklopedisi. 30:39-40 İstanbul: Türkiye Diyanet Vakfı, 2005. Kâtip Çelebi. Tuhfetü'l-Kibâr fî Esfâri'l-Bihâr: Deniz Seferleri Hakkında Büyüklere Armağan. ed. İdris Bostan. Ankara: Başbakanlık Denizcilik Müsteşarlığı, 2008.

Lowry, Heath W. Hersekzâde Ahmed Paşa: An Ottoman Statesman's Career \& Pious Endowments. İstanbul: Bahçeşehir University Press, 2011.

Lowry, Heath W. The Nature of the Early Ottoman State. Albany: State University of New York Press, 2003.

Ludovisi, Daniello de'. 'Relazione dell'Impero Ottomano Riferita in Senato dal Secretario Daniello de' Ludovisi, a dì 3 Giugno del 1534." Relazioni degli Ambasciatori Veneti al Senato, III, v. 1. ed. Eugenio Albèri. Firenze: Tipografia e Calcografia all'Insegna di Clio, 1840.

Mehmed Süreyya. Sicill-i Osmanî. haz. Nuri Akbayar ve Seyit Ali Kahraman. İstanbul: Tarih Vakfı Yurt Yayınları, 1996. 6 cilt.

Mustafa Âlî. Künhü'l-Ahbâr: Dördüncü Rükn, Osmanli Tarihi. Ankara: TTK, 2009.

Mustafa Âlî. Künhü'l-Ahbâr'ın Tezkire Kısmı. ed. Mustafa İsen. Ankara: Atatürk Kültür Merkezi, 1994.

Mustafa Çelebi Celâlzâde. Geschichte Sultan Süleymān Ḳānūnīs von 1520 bis 1557, oder, Tabakāt ülMemālik ve Derecāt ül-Mesālik. ed. Petra Kappert. Wiesbaden: Steiner, 1981.

Navagero, Bernardo. “Relazione dell'Impero Ottomano del Clarissimo Bernardo Navagero, Stato Bailo a Costantinopoli Fatta in Pregadi nel Mese di Febbrajo del 1553", Relazioni degli Ambasciatori Veneti al Senato, III, v. 1. ed. Eugenio Albèri. (Firenze: Tipografia e Calcografia all'Insegna di Clio, 1840.)

Necipoğlu, Gülru. "The Suburban Landscape of Sixteenth-Century in Istanbul as a Mirror of Classical Ottoman Garden Culture." Gardens in the Time of the Great Muslim Empires: Theory and Design içinde 32-71. ed. Attilio Petruccioli. Leiden \& New York: Brill, 1997.

Necipoğlu, Gülru. Architecture, Ceremonial, and Power: The Topkapi Palace in the Fifteenth and Sixteenth Centuries. New York, N.Y: Architectural History Foundation, 1991.

Necipoğlu, Gülru. The Age of Sinan: Architectural Culture in the Ottoman Empire. Princeton: Princeton University Press, 2005.

Neşrî. Cihânnümâ. neşr. Necdet Öztürk. İstanbul: Çamlıca, 2008.

Oflazoğlu, Turan. Sinan. Ankara: Kültür ve Turizm Bakanlığı Yayınları, 1988.

Oruç Bey. Oruç Bey Tarihi: Osmanlı Tarihi (1288-1502), neşr. Necdet Öztürk. İstanbul: Bilge Kültür Sanat, 2014.

Osmanzâde Taib, Ahmed. Hadikatü'l-Vüzerâ. İstanbul: Ceride-i Havadis Matbaası, 1271.

Özcan, Abdülkadir. “Feridun Ahmed Bey." TDV İslam Ansiklopedisi. 12:396-397. İstanbul: Türkiye Diyanet Vakfı, 1995.

Peirce, Leslie P. Empress of the East: How a European Slave Girl Became Queen of the Ottoman Empire. New York: Basic Books, 2017. 
Peirce, Leslie P. The Imperial Harem: Women and Sovereignty in the Ottoman Empire. New York: Oxford University Press, 1993.

Pınarbaşı, Simge Özer. “Mimar Sinan'ı Romanlarla Tanımak.” Art Sanat 8 (2017): 405-423.

Ragazzoni, Jacopo. “Relazione dell'Impero Ottomano di Jacopo Ragazzoni Presentata del suo Ritorno da Costantinopoli, il 16 Agosto 1571." Relazioni degli Ambasciatori Veneti al Senato, III, v.2. ed. Eugenio Albèri. Firenze: Società Editrice Fiorentina, 1844.

Reindl, Hedda. Männer um Bāyezìd: eine prosopographische Studie über die Epoche Sultan Bāyezīds II. (1481-1512). Berlin: K. Schwarz, 1982.

Renier, Alvise. "Relazione." Relazioni di Ambasciatori Veneti al Senato: Costantinopoli, Relazioni Inedite (1512-1789). ed. Maria Pia Pedani-Fabris. Padova: Bottega D’Erasmo - Aldo Ausilio Editore, 1996.

Sakaoğlu, Necdet. Bu Mülkün Kadın Sultanları: Valide Sultanlar, Hatunlar, Hasekiler, Kadınefendiler, Sultanefendiler. İstanbul: Alfa Tarih, 2015.

Selânikî Mustafa Efendi. Tarih-i Selânikî. Ankara: Türk Tarih Kurumu, 1999. 2 cilt.

Şahin, Kaya. "Staging an Empire: An Ottoman Circumcision Ceremony as Cultural Performance." The American Historical Review 123:2 (2018): 463-92.

Şentürk, A. Atillâ Şentürk. Yahyâ Beğ'in Sehzâde Mustafa Mersiyesi Yahut Kanuni Hicviyesi. İstanbul: Enderun Kitabevi, 1998.

Stratton, Arthur. Sinan. New York: Charles Scribner's Sons. 1972.

Trevisano, Domenico. “Relazione dell'Impero Ottomano del Clarissimo Domenico Trevisano, Tornato Bailo da Costantinopoli sulla fine del 1554." Relazioni degli Ambasciatori Veneti al Senato, III. v.1. ed. Eugenio Albèri. Firenze: Tipografia e Calcografia all'Insegna di Clio, 1840.

Turan, Ebru. "The Marriage of Ibrahim Pasha (ca. 1495-1536): The rise of Sultan Süleyman's favorite to the grand vizierate and the politics of the elites in the early sixteenth-century Ottoman Empire." Turcica 41 (2009): 3-36.

Turan, Şerafettin. Kanunî́nin Oğlu Şehzâde Bayezid Vak'ası. Ankara: Türk Tarih Kurumu, 1961.

Uçtum, Nejat. "Hürrem ve Mihrümah Sultanların Polonya Kıralı II. Zigismund'a Yazdıkları Mektuplar." Belleten 44/176 (1980): 697-715

Uluçay, M. Çağatay. Osmanlı Sultanlarına Aşk Mektupları. İstanbul: Șaka Matbaası, 1950.

Uluçay, M. Çağatay. Padişahların Kadınları ve Kızları. İstanbul: Ötüken, 2011.

Uzunçarşıı, İsmail Hakkı. "Gazi Orhan Bey Vakfiyesi." Osmanlı hanedanı üstüne incelemeler: seçme makaleler II içinde 37-49. İstanbul: Yapı Kredi Yayınları, 2012.

Uzunçarşılı, İsmail Hakkı. “Kanunî Sultan Süleyman'ın Vezir-i Âzamı Makbûl ve Maktûl İbrahim Paşa Padişah Dâmadı Değildi." Belleten 39/114 (1965): 355-64.

Varlık, Nükhet. Plague and Empire in the Early Modern Mediterranean World: The Ottoman Experience, 1347-1600. New York, NY: Cambridge University Press, 2015.

Villalón, Cristóbal de. Viaje de Turquia. Madrid: Espasa-Calpe, S. A., 1919. 2 cilt. [Türkçesi: Türkiye Seyahati. çev. Yeliz Demirhan. İstanbul: Erko Yayıncılık, t.y.].

Woodhead, Christine. “Rüstem Pasha." Encyclopaedia of Islam, Second Edition. 8:640-641. Leiden: Brill, 1995.

Yelçe, Zeynep. “Evaluating Three Imperial Festivals: 1524, 1530, 1539." Celebration, Entertainment and Theater in the Ottoman World içinde 71-109, ed. Suraiya Faroqhi ve Arzu Öztürkmen. London: Seagull Books, 2014.

Yüceyılmaz, Muhterem. Has Bahçenin Gonca Gülü: Mihrimah Sultan. İstanbul: Nesil, 2008. 
Yüksel, İ. Aydın. “Rüstem Paşa'nın Vakıfları ve İstanbul'daki Vakıf Eserleri.” Vakıf Medeniyeti Sempozyumu Kitabı, 12-13 Mayıs 2003 içinde 225-246. Ankara: Vakıflar Genel Müdürlüğü, 2003.

Yüksel, İ. Aydın. "Sadrâzam Rüstem Paşa'nın Vakıfları." Ekrem Hakkı Ayverdi Hatıra Kitabı içinde 220279. İstanbul: İstanbul Fetih Cemiyeti, 1995.

Zülfikar, F. Cangüzel. “Mihrimah Sultan'ın Vakıflar Genel Müdürlüğü Arşivinde Bulunan Vakfiyelerinin Değerlendirilmesi." Yüksek Lisans Tezi, Ankara Üniversitesi, 1989. 